Article

\title{
Social Cohesion as the Missing Link between Natural Resource Management and Peacebuilding: Lessons from Cocoa Production in Côte d'Ivoire and Colombia
}

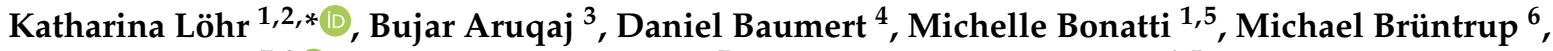 \\ Christian Bunn ${ }^{7,8} \mathbb{D}^{\circ}$, Augusto Castro-Nunez ${ }^{7}$, Giovanna Chavez-Miguel ${ }^{1,5}$, Martha Lilia Del Rio ${ }^{1,5}(\mathbb{D}$, \\ Samyra Hachmann ${ }^{1}$, Héctor Camilo Morales Muñoz ${ }^{1,5}{ }^{(0)}$, Franziska Ollendorf ${ }^{1,9}$, Tatiana Rodriguez ${ }^{1,5}$, \\ Bettina Rudloff ${ }^{10}$, Johannes Schorling ${ }^{4}$, Arne Schuffenhauer ${ }^{11}$, Ingrid Schulte ${ }^{12,13}$, Stefan Sieber ${ }^{1,5}$, \\ Sophia Tadesse ${ }^{2}$, Christian Ulrichs ${ }^{2}$, Claudia Vogel ${ }^{11}$ and Michael Weinhardt ${ }^{14,15}$
}

1 Leibniz Centre for Agricultural Landscape Research (ZALF), 15374 Müncheberg, Germany; michelle.bonatti@zalf.de (M.B.); giovanna.chavez-miguel@zalf.de (G.C.-M.); Martha_Lilia.Del_Rio_Duque@zalf.de (M.L.D.R.); samyrahachmann@gmail.com (S.H.); hector.morales@zalf.de (H.C.M.M.); Ollendorf@iamo.de (F.O.); Leidy_Tatiana.Rodriguez_Torres@zalf.de (T.R.); stefan.sieber@zalf.de (S.S.)

2 Department of Urban Plant Ecophysiology, Albrecht Daniel Thaer-Institute of Agricultural and Horticultural Sciences, Humboldt-Universität zu Berlin, 10115 Berlin, Germany; sophia.tadesse@hu-berlin.de (S.T.); christian.ulrichs@hu-berlin.de (C.U.)

check for updates

Citation: Löhr, K.; Aruqaj, B.; Baumert, D.; Bonatti, M.; Brüntrup, M.; Bunn, C.; Castro-Nunez, A.; Chavez-Miguel, G.; Del Rio, M.L.; Hachmann, S.; et al. Social Cohesion as the Missing Link between Natural Resource Management and Peacebuilding: Lessons from Cocoa Production in Côte d'Ivoire and Colombia. Sustainability 2021, 13, 13002. https://doi.org/10.3390/ su132313002

Academic Editor: Antonio Boggia

Received: 27 October 2021

Accepted: 21 November 2021

Published: 24 November 2021

Publisher's Note: MDPI stays neutral with regard to jurisdictional claims in published maps and institutional affiliations.

Copyright: (c) 2021 by the authors. Licensee MDPI, Basel, Switzerland. This article is an open access article distributed under the terms and conditions of the Creative Commons Attribution (CC BY) license (https:// creativecommons.org/licenses/by/ $4.0 /)$.
3 Institute of Sociology, Freie Universität zu Berlin, 10115 Berlin, Germany; Bujar.Aruqaj@fu-berlin.de

4 INKOTA-Netzwerk e.V., 10115 Berlin, Germany; daniel.baumert@hotmail.de (D.B.); schorling@inkota.de (J.S.)

5 Department of Resource Economics, Albrecht Daniel Thaer-Institute of Agricultural and Horticultural Sciences, Humboldt-Universität zu Berlin, 10115 Berlin, Germany

6 German Development Institute/Deutsches Institut für Entwicklungspolitik (DIE), 53113 Bonn, Germany; Michael.Bruentrup@die-gdi.de

7 Alliance of Bioversity International and The International Center for Tropical Agriculture (CIAT), Cali 763537, Colombia; c.bunn@cgiar.org (C.B.); augusto.castro@cgiar.org (A.C.-N.)

8 Department of Agricultural Economics and Rural Development, Georg-August-Universität Göttingen, 37077 Göttingen, Germany

9 Leibniz Institute of Agricultural Development in Transition Economies (IAMO), 06120 Halle, Germany

10 German Institute for International and Security Affairs (SWP), 10719 Berlin, Germany; bettina.rudloff@swp-berlin.org

11 Gesellschaft für Internationale Zusammenarbeit (GIZ), 53113 Bonn, Germany; arne.schuffenhauer@giz.de (A.S.); claudia.vogel@giz.de (C.V.)

12 Climate Focus, 10119 Berlin, Germany; ingrid.schulte@hu-berlin.de

13 Department of Geography, Integrative Research Institute on Transformations of Human-Environment Systems, Humboldt-Universität zu Berlin, 10117 Berlin, Germany

14 Institute of Sociology, Technische Universität Berlin, 10115 Berlin, Germany; michael.weinhardt@tu-berlin.de

15 Department of Business and Economics, Berlin School of Economics and Law (HWR), 10825 Berlin, Germany

* Correspondence: Katharina.loehr@zalf.de

Abstract: Social cohesion plays a key role in processes of peacebuilding and sustainable development. Fostering social cohesion might present a potential to enhance the connection of natural resource management and peacebuilding and better functioning of sustainable land use systems. This contribution explores the nexus between social cohesion, natural resource management, and peacebuilding. We do so by (1) reviewing literature on the three concepts and (2) studying four different key action areas in the context of sustainable cocoa production for their potential to enhance social cohesion, namely (a) agroforestry; (b) cooperatives; (c) certification schemes; and (d) trade policies. Research is based on experience from cocoa production in two post-conflict countries, Côte d'Ivoire and Colombia. Our findings show that by fostering environmentally sustainable agricultural practices, these key action areas have a clear potential to foster social cohesion among cocoa producers and thus provide a valuable contribution to post-conflict peacebuilding in both countries. However, the actual effects strongly depend on a multitude of local factors which need to be carefully taken into consideration. Further, the focus in implementation of some of these approaches tends to be on increasing agricultural productivity and not directly on fostering cocoa farmers' wellbeing and 
societal relations, and hence a shift toward social objectives is needed in order to strengthen these approaches as a part of overall peacebuilding strategies.

Keywords: social trust; environmental peacebuilding; sustainable development; natural resource management; sustainable cocoa production

\section{Introduction}

In the context of post-conflict societies, natural resources management (NRM) is recognized as an important toolbox in the transition toward durable peace [1,2]. The stage of 'post-conflict' is not only characterized by the end of armed combat, but also potential ongoing processes of reconciliation and building resilience to future conflict risks. NRM includes the utilization of natural resources, such as land, water, air, minerals, forests, fisheries, wild flora, and wild fauna, in a way that is sustainable, meaning that the longterm provision of ecosystem services is ensured [3]. NRM approaches to peacebuilding show potential to tackle collectively socio-ecological problems and to reduce inequalities related to access and distribution of the natural capital simultaneously, thereby fostering trust and cooperation among actors [4,5]. On the other hand, there are numerous examples where the forceful appropriation of natural resources (land grabbing) and ecologically unsustainable and socially unfair exploitation (water grabbing, soil mining, and desertification) have done exactly the opposite-namely, created social unrest and conflict [6-8]. In these regards, NRM is intricately linked to social cohesion and peacebuilding.

Social cohesion describes the vertical and the horizontal relations among members of society [9]. It is influenced by levels of socio-economic inclusion, as well as societal relations defined by levels of trust, sense of belonging, and willingness to cooperate $[9,10]$. NRM activities in a given community are likely to significantly influence community cohesion by creating spaces for stakeholder interaction, thereby strengthening levels of trust, collaboration, and inclusion [11,12]. Therefore, in post-conflict contexts where dispute over access to land and other natural resources was part of the conflict, developing agricultural production models that enhance the sustainable use of resources can provide opportunity for building sustainable peace on all three dimensions (environmental, economic, and social), and also contribute towards other development goals such as climate change mitigation. Such models should successfully address the need for income generation and sustaining rural livelihoods, as well as ecological sustainability, carbon capture and/or greenhouse gas emission reduction, climate change adaptation, and biodiversity conservation [13-15]. Aligned with this logic, this paper follows the notion of environmental peacebuilding as key concept $[4,16]$. Environmental peacebuilding assumes that joint natural resource management provides opportunities for strengthening cooperation and trust- - two crucial indicators of social cohesion - that ultimately contribute to peacebuilding $[4,16]$.

Over the course of the past two decades, the relevance of social cohesion in peacebuilding is increasingly recognized by governments and international donor organizations. Institutions such as the UN Development Program, the World Bank, and the OECD acknowledge that the avoidance of social fragmentation and the (re-)establishing of trust between social groups and the state is crucial for ensuring peacebuilding efforts to be successful $[17,18]$. Building long-lasting peace involves a wide range of activities and functions needed for transforming conflict towards more sustainable, peaceful relationships [19]. As suggested by Pearce, processes need to be put into place "which foster and strengthen local capacity to deal with the past, to engage with the present, and to shape the future in ways which do not exclude, oppress, or divide." [20] (p. 448). This relates to the concept of positive peace advanced by Galtung [21], which proposes that not only an absence of violence is sufficient for consolidating sustainable peace; but also that trust and collaboration, as well as negotiation capacities between community members, must be reinforced [20]. Nevertheless, as a dynamic social construct, peacebuilding poses many challenges and 
requires attentive maintenance to be actively sustained, thereby involving efforts from all levels of governance [18]. Furthermore, social cohesion comprehends inclusivity in economic, social, and civil political participation, which in turn contributes to reduce the risk of anti-social behavior that can lead to violent extremism [18].

The aim of this paper is to improve the understanding of the interrelations between NRM, social cohesion, and peacebuilding. The following research questions underlie this paper's study:

RQ1: What are theoretical interlinkages between social cohesion, NRM, and peacebuilding? RQ2: What potential do selected key action areas provide for the strengthening of social cohesion in the context of NRM?

To answer these questions, we draw on a literature review and on experts' experiences working with development interventions targeting sustainable cocoa production (as a specific form of NRM) and peacebuilding. These are based on a review of the Expert Forum on the topic of Enhancing Social Cohesion through Sustainable Cocoa Production held on 13 February 2020, at the Humboldt-Universität zu Berlin (Germany). A total of about 40 participants attended the one-day event, including representatives of academia, civil society, political communities, and the cocoa and chocolate industry. We take sustainable cocoa production in Côte d'Ivoire and in Colombia as suitable case studies to explore the nexus of social cohesion, NRM, and peacebuilding. This allows us to compare two different post-conflict contexts and to gain insights that-we argue-are also applicable to a wider understanding of NRM in such contexts in particular and for social cohesion building more generally. We emphasize that this study is not an in-depth empirical investigation, but rather a conceptual contribution, in which we draw on broad spectrum of empirical insights to answer the research questions and substantiate and illustrate our general argument.

\section{The Interconnectedness between Social Cohesion, Peacebuilding and Natural Resource Management}

\subsection{Natural Resource Management and Peacebuilding}

Whilst historically, natural resources and environmental issues were predominantly regarded as a source of conflict, in recent years their potential to motivate cooperation, transformation, and the consolidation of peace is acknowledged [12]. Natural resources and the environment can essentially contribute to peacebuilding in two ways: (1) Through economic development and the generation of employment and (2) the cooperation over the management of shared natural resources, which can provide new opportunities for peacebuilding $[2,22]$. The second, the aspect of cooperative resource management, is now referred to as Environmental Peacebuilding [4,12]. It builds on the assumption that NRM enables cooperation by creating spaces for collaboration of stakeholders and, thus, establishes contact, bonds, and, ultimately, networks between previously warring social groups, which can translate into increasing social cohesion and peacebuilding. The relationship between NRM and peacebuilding, however, remains ambivalent, as there are a multiplicity of land use and governance approaches. Thus, natural resources can also contribute to a relapse into conflict if not managed properly, usually in the first five years after peace agreements [23]. This might relate to the fact that most peace negotiations do not address NRM mechanisms despite the conflict often being a consequence of their allocation. Therefore, "integrating environment and natural resources into peacebuilding is no longer an optionit is a security imperative" [2] (p. 5).

High-value resources prove to potentially yield substantial revenues, thus are often understood as factors supporting violent conflict, for example through financing conflict parties or through disputes around access to, and ownership of, resources $[2,7,8,24,25]$. Such high-priced natural resources that can affect conflict dynamics range from 'lootable' resources such as diamonds, coltan, or timber, to those requiring extensive mechanized infrastructure such as oil or gas, to agricultural products such as coffee, bananas, or cocoa, and to illicit substances such as cocaine or opium [1]. While conventional agricultural 
commodities are often overlooked in this category, profitable export goods are also linked to the offset of armed conflict [7,8]. In particular, cocoa is identified as a causal factor for conflicts in Liberia (1989-2003), Sierra Leone (1991-2000), and Côte d'Ivoire (2002-2007) [2]. In Colombia, conflict has been mainly fuelled by revenues from extracting oil, gold, timber, and emeralds and cultivating illicit crops, particularly coca $[2,7,26])$.

Nevertheless, with regards to their potential for generating increased revenues, high-value resources can also promote peace. Earnings can help to jump-start development, secure sustainable growth, raise living standards, and increase economic equality, while also serving as an important source of foreign currency for cash-strapped governments [24]. High-value resources can help reduce dependence on international aid, and support compensation and post-conflict relief for war-affected populations [24]. Reports by the UN Secretary-General and World Bank emphasize the need to rely on high-value natural resources for development and peacebuilding, especially when aiming at sustainable long-term post-conflict peace $[27,28]$. Despite these prospects, several natural resource-abundant countries appear to be unable to maintain long-term peace [24]. Against this background, it is critical to explore NRM approaches that support peacebuilding processes [1]. In the following, we argue that social cohesion may play a vital role as link between NRM and peacebuilding.

\subsection{Social Cohesion and Peacebuilding}

Social cohesion is a longstanding key concept in various disciplines within social and political sciences. Over time, many different definitions and conceptualizations have been proposed, with authors referring to its key components such as social integration, solidarity, equality, place attachment, or identity, all attributable to a collective, i.e., a community, neighborhood, region, or society as a whole $[29,30]$. Social cohesion reflects the level of connectedness, interpersonal trust, and reciprocity within a social group, as well as norms of behavior, codes of conduct, conventions, and habits. These institutions are central to maintaining cooperation in social units and avoiding their disintegration. Institutions refer to the rules that members of a certain group are expected to comply with without any external re-enforcement. Such institutions may be formal state-organized or informal, the latter often being under-appreciated. For example, traditional farming societies often share a common understanding of the natural processes occurring in a given territory. This collective frame of reference for interpreting reality is often deeply intertwined with the existing territorial identities, which can influence cohesion levels in regards of the sense of rootedness shared by members of a society [31].

Accordingly, scholars and practitioners often see social cohesion as an important determinant of a peaceful, democratic, and prosperous society [17]. For example, traditional farming societies often share a common understanding of the natural processes occurring in a given territory. This collective frame of reference for interpreting reality is often deeply intertwined with the existing territorial identities, which can influence cohesion levels in regards of the sense of rootedness shared by members of a society [31]. The United Nations Development Programme (UNDP) describes the meaning of social cohesion in post-conflict peacebuilding as follows:

"[Social cohesion is] an elusive concept easier to recognize by its absence than by any definition. A lack of social cohesion results in increased social tension, violent crime, targeting of minorities, human rights violations, and, ultimately, violent conflict. Social cohesion is about tolerance of, and respect for, diversity (in terms of religion, ethnicity, economic situation, political preferences, sexuality, gender, and age)—both institutionally and individually" [32] (p. 14).

In a review, Langer et al. [33] identify economic equality, trust, and identity as key determinants of social cohesion. In line with these, they distinguish three levels for building social cohesion: relationships among individuals of the same group (depending on the extent of perceived inequalities); relationships among individuals across groups (translating into societal trust); and relationships between individuals, groups, and the 
state (people's adherence to a national identity). In the peacebuilding context, the first two are often understood as horizontal cohesion, social cohesion between members of society (e.g., communities and civil society organizations), and the latter as vertical cohesion, between state and society $[9,34]$. Improving horizontal and vertical cohesion-e.g., through reducing inequalities (as a conflict driver) and building social capital-has come to be considered a crucial factor for fostering sustainable development and peace $[35,36]$ and, therefore, a focal point for peacebuilding interventions.

Previous academic work suggests that intergroup conflict shapes emotional bonds between members of the same group, promotes positive in-group and negative out-group stereotyping, encourages self-sacrifice for the group, and changes the social structure of groups [37]. Accordingly, in polarized, post-conflict societies, intergroup tensions can weaken attempts to re-build local institutions, thereby undermining efforts to re-establish peace at the level of horizontal cohesion [9]. Thus, in post-conflict societies it is crucial to address questions of transitional justice, compensation to victims, truth of what happened during conflict, and reconciliation processes in the long term in order to foster cohesion building across different (formerly conflicting) groups [19].

Controversially, international donor organizations often focus on the reconstruction of destroyed infrastructure and formal governmental institutions, neglecting the reconstruction of deeply broken social relationships, which is equally important for the stability of peace and the effectiveness of development efforts [38]. Fearon et al. [29] suggest that external development aid can foster social cohesion after civil war by supporting strong institutions at the local level-if they persist after the development programme ends. However, interventions are often implemented with neither sufficient understanding of antecedents of the conflict nor of the local dynamics of social cohesion needed for amending deep-rooted social relationships that make peacebuilding efforts successful [39].

\subsection{Natural Resource Management and Social Cohesion}

While the internal links between social cohesion and peacebuilding are intuitively clear, the links between social cohesion and NRM are less obvious. However, there is quite good research that finds that without social cohesion and institutions, (sustainable) NRM (at least of not fully privately owned resources) is unlikely and resources are degraded $[40,41]$. It may be argued that they have a reciprocal relationship: Social cohesion could be understood as a prerequisite for sustainable NRM, with NRM, in turn, becoming an entry point to strengthening social cohesion in wider society. The maintenance of peaceful social dynamics results in a cohesive social structure and vice versa, thereby relating directly to the capacity of a society to maintain the conditions for using their resources sustainably [42]. In other words, as a society becomes more cohesive, its members are more likely to socialize information and arrive at a consensus over a proposed plan of action for preserving its natural capital [42].

Figure 1 visualizes the interlinkages between the three different concepts. From the discussion we can see that NRM is not straightforward for all peacebuilding processes but it could be embedded as it offers resources such as job opportunities, income, and an intact environment that may support peacebuilding. In the opposite direction, the process of peacebuilding might affect NRM through a change in the accessibility of certain regions and resources as well as changes in the patterns of resource use (e.g., production and consumption practices that change in times of peace). However, the link between NRM and peacebuilding may also work through the involvement of social cohesion, which many see as a requirement and precondition for societal reconciliation and stability. Thus, NRM may also impact peacebuilding indirectly through social cohesion as it provides an entry point for strengthening social cohesion in a given community or society. Here, again, this is not necessarily a one way street. Social cohesion may be seen not only as a prerequisite for peacebuilding, but also for NRM practices and sustainability more generally [40]. In addition, active peacebuilding measures provide space for creating and improving social cohesion. How these conceptual links which are possible theoretically eventually 
work out in the field will need be investigated empirically. In any way, acknowledging the interlinkages, we argue, has important practical implications on how NRM and efforts to strengthen social cohesion are integrated into development interventions.

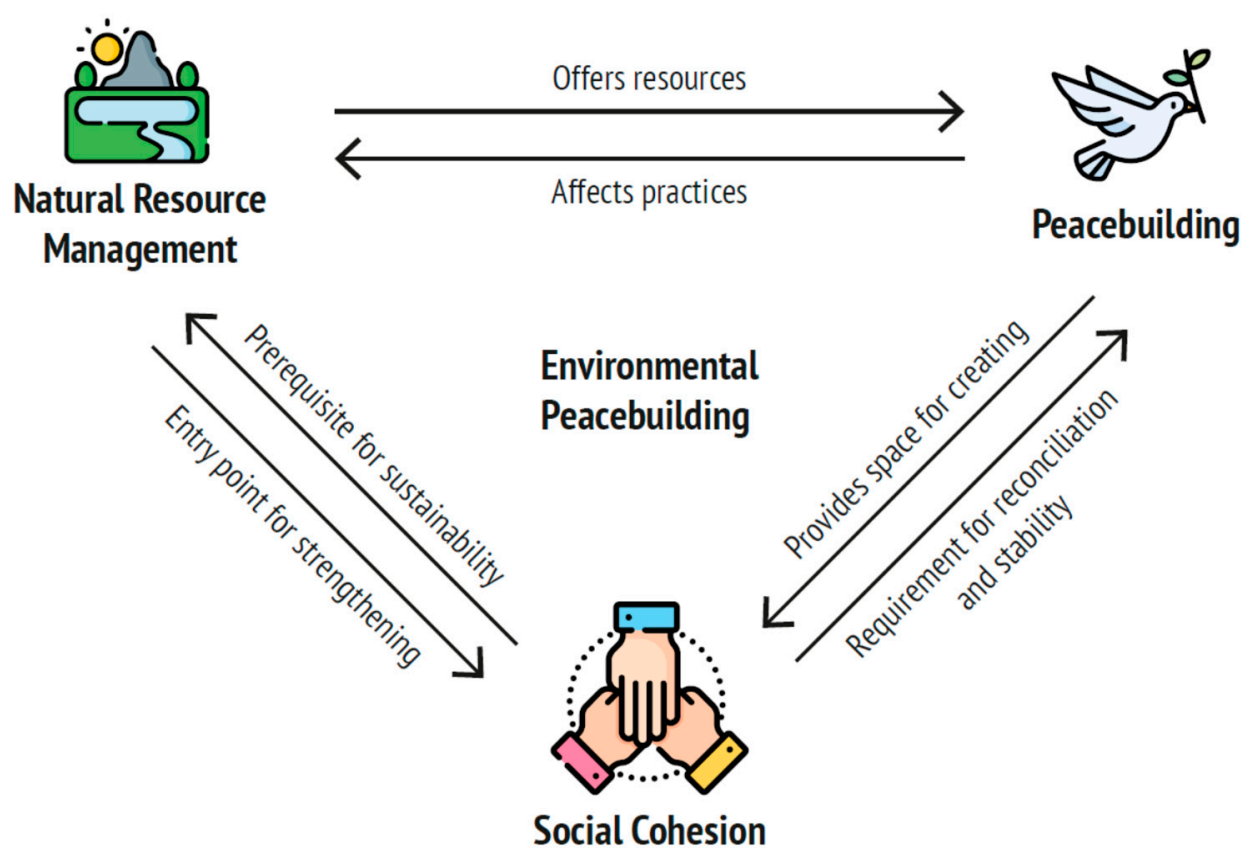

Figure 1. The nexus between natural resource management, social cohesion, and peacebuilding (own design).

\section{Four Action Areas to Foster Social Cohesion in the Cocoa Sector}

In the following, we present four NRM action areas that we argue have the potential to strengthen social cohesion using cocoa production as an example: (a) agroforestry production schemes at the community level, (b) cooperatives and collective organization; (c) national trade and price policies; and (d) international certification schemes. While these are all typical elements of many cocoa value chain support interventions for enhancing farm productivity and business skills, they are rarely used with the explicit goal of enhancing elements of social cohesion, such as trust and collaboration. The strengthening of social cohesion is rarely an objective in ongoing agricultural development interventions, because they have been developed and are usually applied in peaceful environments. However, in post-conflict (as well as in latent-conflict) environments, this neglect is unacceptable since without creating peace an essential ingredient of long-term sustainable development will be missing. Unfortunately, the agricultural intervention genesis and logic makes it challenging to present effective approaches to foster social cohesion and creates the need to analyse their potential.

Figure 2 depicts how the action areas are embedded in the societal context and chains of production, from farmers and producers, along wholesalers and retailers, international markets and other intermediaries up to the consumers of the final product. While (a) agroforestry relates more directly to a production system in the cocoa producing countries, (b), (c), and (d) are more related to overarching social structures. However, even (a) is often deeply intertwined with social rules since in many land-abundant societies worldwide with informal land rights (which is typical for many cocoa producing regions), forestry practices often are associated with land-ownership [43,44]. The areas also focus on different societal levels and range from the individual and communal farm level (agroforestry production schemes), to the sub-national respective organisational level (cooperatives and organisational changes in production due to certification schemes), as well as the national and governmental level (agricultural and price policies) and even the international and global level (certification schemes). To a certain extent, these actions areas are layered and hierarchical, so that 
each of them also affects the actors and practices which are located at lower societal levels. While the depiction is a simplification from the complexities of the real world (for example, there are of course also international trade policies that frame and determine the practices discussed here), Figure 2 is meant to provide orientation on the context of the four action areas discussed in the following sections.

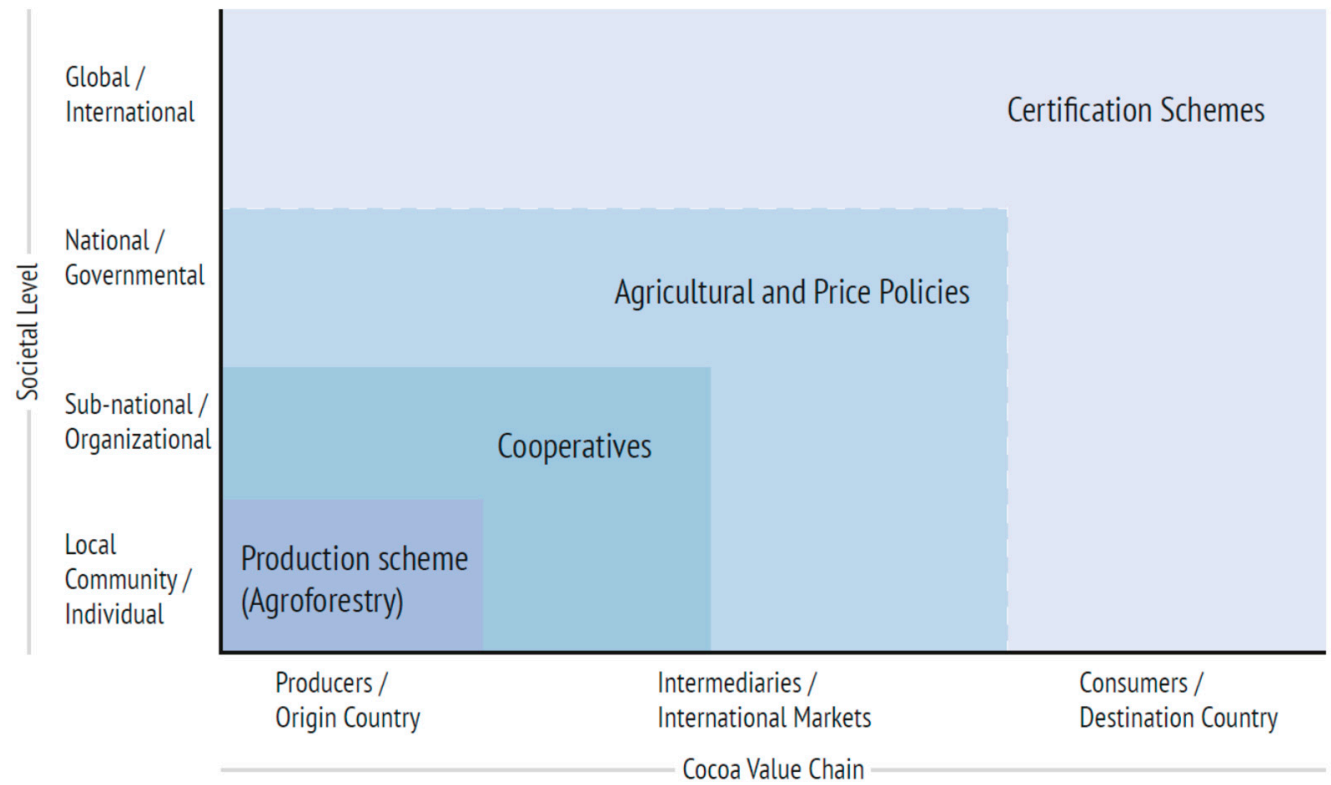

Figure 2. Four exemplary action areas with the potential to strengthen social cohesion in post-conflict cocoa production, ranging from the producer to the consumer levels (own design).

\subsection{Case Selection: Cocoa Production in Côte d'Ivoire and Colombia}

\subsubsection{Case Study Countries: Colombia and Côte d'Ivoire}

As country cases, Côte d'Ivoire and Colombia are chosen for a comparative approach. Although both countries are cocoa producers with strong external trade linkages, represent two important civil-war stories linked to cocoa and presently face post-conflict scenarios (even though the two countries can be defined as post-conflict due to the official signing of Peace Treaties, in both, high levels of tension and violence continues) with various initiatives and programmes to promote the development of their national cocoa sectors, they have very different characteristics. While Côte d'Ivoire is leading global production as the greatest worldwide supplier and exporter of cocoa, Colombia only produces around $1 \%$ of the world's produced cocoa and mainly focuses on domestic demand; but with high interest to enter external markets [45]. In Colombia, cocoa is now promoted as a means of substitution for illegal crops (i.e., coca leaf production) and as an alternative to livelihoods connected to deforestation [45]. In Côte d'Ivoire, cocoa export has a long history and continues to be the most important export revenue. Looking at socio-political conflicts in both countries, we argue that the production of cocoa as a high-value crop can promote peace, because its revenues can support domestic economic development and enable smallholder farmers to make a decent living. At the same time, traditional cocoa production in agroforestry systems can foster ecological restoration and conservation of forests, supporting the sustainability of development.

\subsubsection{The Cocoa Sector}

Sustainable cocoa production is used as an example in this study to explore the nexus of social cohesion, NRM, and peacebuilding. In 2018, annual global production of cocoa amounted to around $4-5$ million tons [46], reaching an all-time high [47]. While cocoa containing products are predominantly consumed in the Global North, cultivation exclu- 
sively takes place in the Global South because cocoa production requires tropical conditions. We chose the case of cocoa production because, on the one hand, the geographical distribution of cocoa production often coincides with the presence of more intense sociopolitical conflicts. Most cocoa producing countries rank low on the Global Peace Index, which considers societal safety and security, the extent of ongoing domestic and international conflict, as well as the degree of militarization [48]. Côte d'Ivoire ranks 107th and Colombia ranks 143rd out of 163 countries [48]. On the other hand, cocoa is a high-value crop with the potential to promote peace, because its revenues can support national economic development and enable smallholder farmers to make a living in the long-term. The cocoa sector provides for the livelihood of around 40 to 50 million people (2012) and around 5 million households. Unlike other cash crops grown on plantations controlled by multinational companies, $70 \%$ of all cocoa is produced by smallholder farmers [49]. In peacebuilding processes, the social role of smallholder farmers is particularly important given their cultural relationship with the environment and the land's role for breeding conflict and accommodating rebels [50].

The global cocoa chocolate value chain faces a number of severe sustainability challenges that may jeopardise the long-term sustainability of cocoa production and producers' wellbeing. There is a high degree of asymmetry in distribution of value added in the cocoa chocolate chain. In 2015, all of the millions of cocoa producers received collectively only $6.6 \%$ of the price of the end product chocolate bar; the rest went to the downstream segments (processing, manufacturing, and retail) [51]. The low and strongly volatile cocoa price is a major reason for the high prevalence of extreme poverty among many cocoa producers, especially in the two main producing countries Côte d'Ivoire and Ghana. Many challenges at the production level are closely related to poverty $[51,52]$. Child labour, both own and hired, is one of the most serious labour rights violations in the cocoa sector. Poverty is considered a root cause as it prevents households from hiring adult farm laborers or sending their children to school [51]. At the same time, poverty has the potential to undermine social trust and cohesion.

Cocoa production also can have negative environmental impacts due to the destruction of primary forest habitat, soil erosion, and the use of chemicals [53]. In Côte d'Ivoire, cocoa is by far the main driver of deforestation in the country. From 1985 to 2019, forest loss was $60.80 \%, 46.39 \%, 20.76 \%$, and $51.18 \%$, respectively, in the first epicentre of cocoa production in the East, the second epicentre in the Centre-West, the third epicentre in the South-West, and the new production region in the West of Ivory Coast [54]. This corresponds to the situation in other West African cocoa producing countries as well [53]. Furthermore, the hard work with little returns, limited rural infrastructure, and difficult access to important input factors make cocoa production ever less attractive for rural youth. The loss of a positive outlook and future within the local production system regarding income and employment opportunities possibly undercuts and weakens relations across generations, threatening the persistence of traditional ways of living and local communities.

As trade product for both countries, cocoa contributes to the economic welfare. Cocoa and cocoa preparations are Ivory Coast's leading export products accounting for around $40 \%$ of its total exports (2019) [55]. Around $24 \%$ of cocoa and cocoa preparations are exported to the Netherlands, $12 \%$ to the United States and around $8 \%$ to France, Germany, and Belgium, a majority of cocoa is thus delivered to European countries (2019) [56]. Colombia is trading cocoa mainly nationally, with less than $1 \%$ being exported (2020) [57]. The main export countries for cocoa and cocoa preparations are Mexico (18\%), the United States (17\%), and Ecuador (13\%) (2019); accordingly, the Colombian cocoa trade is concentrated on the American market [58]. Overall, the EU's consumption of cocoa products is globally leading and grows at 5\% a year [59]. At the same time, however, Europe is the largest exporter of chocolate, indicating that processing takes place here and not in the countries of origin for cocoa [59]. 


\subsection{Production Scheme: Agroforestry}

Agroforestry Systems (AFS) are sustainable land management strategies that deliberately integrate woody perennials such as trees, shrubs, and palms within farming systems $[60,61]$. They are traditionally employed by smallholder farmers throughout the tropics and promoted as a sustainable livelihood alternative by land use managers and international development efforts [60,62]. Examples of AFS include home-gardens, silvopastoral systems, and other shaded tree-crop systems, such as cocoa agroforestry systems [63]. AFS show, among others, positive effects on biodiversity conservation and climate change adaptation and mitigation, as well as sustainable rural livelihoods [64-66].

Cocoa agroforestry systems (CAFS) are complex multi-species cropping systems where cocoa trees are the main constituent and are cultivated next to other crops or woody tree species [67,68]. Ruf [69] defines a CAFS as a "cocoa farm which has more than 15 mature timber trees per hectare (and possibly as many as 60-80), usually giant trees more than $15 \mathrm{~m}$ tall, which are native to the natural tropical forest" [69] (p. 376). Moreover, such a complex cocoa farm assures a large variety of biodiversity and since it consists of many different trees such as fruit and wood trees as well as a variety of shrubs and other plants, it manifests several levels of canopy storage [69]. Cocoa production in agroforestry systems can foster ecological restoration and conservation. This is vital for post-conflict $\mathrm{NRM}$, as conflict transformations are shown to increase deforestation and other extractive activities [70]; for example, when areas formerly controlled by armed groups become more accessible, as is the case in Colombia [13,14]. At the same time, Colombia, as well as Côte $d^{\prime}$ Ivoire and other cocoa-growing countries are biodiversity hotspots where the threat of ecological destruction appears especially pertinent [53]. In this context, CAFS may offer an approach that reconciles agricultural production and the need for biodiversity conservation. Though CAFS still need to be considered more as a compromise as they will not be able to compensate loss of primary (hotspot) forest but are better than pure agriculture.

In terms of social benefits, CAFS are said to contribute to peacebuilding because the preservation or reestablishment of healthy ecosystems is crucial for long term peace in rural societies from an environmental perspective, but also from an economic perspective by enhancing productivity and contributing to improved incomes. Further, when linked to trainings on good agricultural practice, CAFS can also contribute to enhanced social relations by offering spaces for farmers and other stakeholders to meet and interact. Thus, CAFS have the potential to foster social cohesion through the provision of income and social connections.

Agroforestry systems not only have ecological benefits and support local livelihoods, they also include knowledge transfer, since diverse agricultural knowledge is necessary for the maintenance of complex agroforestry systems [71]. Cocoa farmers often rely on their local social networks for informal information about agroforestry-related practices, including shade management, species selection, and site planting patterns [72]. The involvement of local communities within agroforestry extension services beyond facilitating knowledge transfer, could increase social proximity among farmers as well as strengthen informal networks [72]. The participation of cocoa farmers in training programs involving agroforestryrelated practices by means of farmer field schools can further strengthen within-group and between-group social cohesion among them and enhances individual social skills [73]. Everyone working together for a common goal that yields benefits to the wider society. However, the impact of agroforestry systems on societal change is very context dependent and not a given outcome. If trainings focus solely on knowledge transfer to the farmers, little impact on societal relations between local actors is likely. Thus, developing training concepts on this matter requires a political devotion to agroecology and should provide sufficient spaces for interaction and social learning amongst trainees, taking into consideration power relations and applying conflict sensitive approaches.

\subsubsection{Colombia}

In the Colombian context, cocoa cultivation in agroforestry systems is regarded as a promising strategy for reforestation and soil recovery-particularly in areas previously 
used for cattle ranching $[45,74,75]$. Deforestation is mainly driven by livestock expansion, coca leaf cultivation, illegal timber extraction, mining, and infrastructure development [76]. In this context, actors from the Colombian cocoa sector seek to promote cocoa cultivation in agroforestry systems as an approach to decreasing deforestation. On 17 July 2018, the Colombian government, Colombia's National Federation of Cocoa Growers (FEDECACAO), Casa Luker (a Latin America-focused Chocolate manufacturer), the World Resources Institute (WRI), and the Sustainable Trade Initiative (IDH), supported by the World Cocoa Foundation (WCF), signed the joint framework for action to reduce deforestation and promote the protection and restoration of forest in Colombia's cocoa supply chain [77]. In 2019, an action plan on how to promote the objectives of the Initiative on Cocoa, Forests and Peace in Colombia (Iniciativa Cacao, Bosques y Paz) was released. The action plan, which is managed and coordinated by the national development organization ALISOS, was the result of various roundtables with different national and international value chain actors that expressed and involved their perspectives and interests in enhancing a sustainable, agroforestry-based cocoa future in Colombia [78,79].

As outlined above, cocoa production can provide an alternative income source to the cultivation of illicit crops and thus represents an essential opportunity to foster rural development [45]. This is particularly important since the illegal economy of illicit crops is a major component in financing armed groups and sustaining the violent conflict in regions where agroforestry has a great potential. Abbott et al. stress that " $[t]$ he Colombian cocoa sector presents opportunities specifically in the context of post-conflict development" [80] (p. 13). It thus has a strong potential to support lasting peace as rural dwellers find an equally highly valued farming activity that importantly does not spur and finance continuation of conflict. Areas that have been severely affected by the armed conflict in the past account for $34.2 \%$ of the national agricultural area destined for cocoa production [80]. Furthermore, establishing cocoa cultivation in agroforestry systems and protecting local environment, instead of employing monocropping-like illicit coca production schemes, can contribute to rural development objectives and foster social cohesion by creating new links between rural actor groups including new forms of cooperation which may translate into mutual trust, by generating employment and, thus, reducing economic poverty, inequality, and migration among the rural society [45]. Equally important, a sense of belonging to a new community of practice can increase the perception of trust and cooperation, which are key factors in the concept of social cohesion. This, in the context of a Colombian society that has suffered so many traumas due to violence and struggles to trust and build collective action, is crucial to foster reconciliation and consolidate peace.

\subsubsection{Côte d'Ivoire}

Cocoa agroforestry systems in Côte d'Ivoire have a complex history. Working on cocoa farms was a process through which internal and external migrants could eventually gain access to land and become cocoa smallholders themselves [81]. In the 1960s, the government opened forest frontiers by declassifying reserve areas and drawing in foreign labor from neighboring impoverished regions and countries, such as Burkina Faso. Agroforestry was traditionally practiced by indigenous farmers; this shifted to rapid forest conversion with the entrance of these new farmers looking to claim land and gain quick returns on production [81]. The settlement of migrants was facilitated by a customary system marked by land-abundancy, labour-restricted economy (frontier economy) that offered migrants "empty" space and the right to settle for a certain number of years as laborer [82]. With migrant families settling permanently, their descendants claiming long-term rights, during the economic down turn and tumultuous political period and conflict that followed, migrants were stigmatized and at the same time claimed political rights [83]. Thereby, the two civil wars in Côte d'Ivoire since 2002 are to a certain extent attributable to the extremely successful expansion of cocoa production [84]. Today, reforms to land tenure and formalization processes continue to reflect disparities between social groups and remain a source of tension in the country $[83,85]$. In addition to being a potential source of conflict, 
the exclusion of groups from a secured access to land may hamper their investments into trees and other agro-ecological practices, and thereby hinder the expansion of agroforestry systems and its associated societal benefits.

Under the roof of the public-private Cocoa and Forests Initiative (CFI, led by the WCF), the government of Côte d'Ivoire actively supports agroforestry systems [77]. Well-designed agroforestry programs could contribute to protecting and restoring forests, sustainably producing cocoa, and enhancing farmer livelihoods, social inclusion, and community engagement [86], all of which are important requisites of social cohesion in a post-conflict setting. Agroforestry is also embedded in Côte d'Ivoire's REDD+ (Reduced Emissions from Deforestation and Forest Degradation and conservation, sustainable management of forests, and enhancement of forest carbon stocks in developing countries) strategy and other national policies such as the National Forest Strategy and National Agriculture Investment Plan, demonstrating alignment within government priorities [86]. Despite this theoretical devotion to agroforestry, trainings on good agricultural practices within FFS mainly talk about the need of a certain number of shade trees to maximize cocoa production (18-25 forest trees per hectare), which is barely realized, and tend to ignore farmers' existing practices and interests in agro-forestry systems [87]. Thus, environmental and social impacts need to be studied with caution.

We argue that the potential of agroforestry systems to succeed in Côte d'Ivoire, thus contributing to social cohesion by reducing inequalities and fostering social relations, relies on strong political devotion providing strong incentives, secured land ownership, inclusion, and education to all farmers, in particular, more vulnerable groups. The clear and transparent regulation of land ownership can also prevent the flaring up of conflict and hence supports long-term peacebuilding. However, the uptake of agroforestry is limited because there is not just a lack of knowledge and information, but also scarce resources and money to invest in such practices [88]. There is an opportunity here for diverse stakeholders to collaboratively develop integrated land management plans as well as for the government and private sector to support inclusive development. In addition, the existing agroforestry-based innovations that indigenous and migrant farmers alike are already putting into practice $[89,90]$ must be recognized in sector strategies and supported on a larger scale. These strategies represent a high level of local ownership and therefore can have strong positive impact on social cohesion at the horizontal level. If existing local initiatives became strong support from national institutions, a great case for the enhancement of vertical social cohesion would be also made. However, the further expansion of cocoa into new regions must be halted, and the only way (apart from higher prices, which may lead in turn to high production intentions) to accommodate a growing number of farmers and to increase the well-being of these farmers is through increases of land and labor productivity on the existing land, and thus intensification. Combining all objectives requires participatory research and knowledge management.

\subsection{Cooperatives and Collective Organization}

The International Cooperative Alliance defines a cooperative as "an autonomous association of persons united voluntarily to meet their common social, economic and cultural needs and aspirations through a jointly-owned and democratically-controlled enterprise" [91] (p. 43). Cooperatives serve, among other things, as contact points for exporters and third-party certification. In many cocoa-producing regions, cooperatives play a crucial linking role in the cocoa value chain, bridging the gap between farmers and markets, and in some cases are even the exclusive providers of extension services and supplies to farmers in rural areas. With regards to the limited resources available to individual members, cooperatives create economies of scale among smallholders and are recognized as an essential-sometimes the only—vehicle for generating higher returns for farmers and reducing rural poverty. As small-scale farmers organize through cooperativism, they may increase their supply and, thereby, their bargaining power vis-a-vis processors, traders, and exporters, all of whom usually demand large bulk supplies. Functional cooperatives 
enhance social cohesion to properly coordinate their collective action and a cohesive society has a higher potential to constitute cooperatives legally.

Furthermore, groups of farmers organized in cooperatives can provide vital assistance to rural communities. Among their many potential contributions are enhancing associative, organizational, and economic processes, creating vital networks for mobilizing resources, establishing strategic networks and markets, as well as politicizing rural communities to defend their rights and interests. Thus, rather than relying on external support, self-organized farmers can promote self-empowerment among peasants and amplify collective capacities. [73].

\subsubsection{Colombia}

In Colombia, the important role of cooperatives (known as farmers' or producers' associations) in rural development during the post-conflict stage was highlighted by the High Commissioner for Peace in 2014. Cooperatives provide needed services in rural areas that governmental institutions did not yet provide. These include the construction of tertiary roads, of storage and processing facilities, and irrigation, among others. Similarly, cooperatives contribute to the provision of public goods, such as education, infrastructure, health, recreation, technical assistance, and nutrition, among other services, that improve the welfare of rural communities [92]. Cooperatives not only have the potential to contribute to the socioeconomic development of regions, which were and still are most affected by the armed conflict in Colombia [93], but constitute a vital tool for reconstructing the countryside. Furthermore, cooperatives development plays a crucial role in the implementation of the first point in the peace agreement, namely the integral rural reform. This chapter emphasizes privileging cooperative forms of agricultural production and the development of local economies, labour protection and technical assistance [94].

Despite the potential of cooperatives, the associative spirit in the rural sector is still very low, as only $6 \%$ of producers are linked to a cooperative in Colombia [95]. In 2018, a total of 221 cooperatives were dedicated mainly to the agricultural and food industry sector. Gutierrez [92] reviews different indicators to determine that the main conditions for effective development of agricultural cooperatives are not always sufficiently met in Colombia. Land tenure is one of these indicators. In other words, the high degree of inequality in land ownership in Colombia and the informality in land acquisition processes impede adequate access to land for smallholders and is a main driver of both deforestation and conflict [6]. Additionally, the disparity in the availability of agricultural infrastructure, as well as the significant land quality gap known as latifundio (largest estates have the best quality land in comparison with smallholdings), play a crucial role. Further, poorly defined land property rights lead to a lack of appropriate collateral for rural associations to guarantee the repayment of credit loans. Poor access to loans is yet another hurdle to overcome when establishing agricultural cooperatives [92].

Given these multiple challenges, the positive role of cooperatives to foster social cohesion and support peacebuilding in Colombia is not used to its full potential yet. Here again, government's dedication to support rural development and regulating the access to land would create the needed structures to facilitate the spread of cooperatives. This dynamic could be supported by other incentives for the formation of cooperatives and trigger the expected positive dynamics and effects on social cohesion and peacebuilding.

\subsubsection{Côte d'Ivoire}

Cooperatives in Côte d'Ivoire follow the "Organisation for the harmonisation of business laws in Africa" (OHADA) cooperative law, meaning they are intended to be jointly owned, democratic organizations that provide services to their members, at the lowest possible operational cost [96]. According to Le Conseil du Café-Cacao (Coffee and Cocoa Council), $52 \%$ of cocoa farmers are a part of over 1500 registered cooperatives, though other sources report that only $20 \%$ of farmers are members of cooperatives [97]. However, in many cases, the functionality of cooperatives is limited due to poor management, a lack 
of funding and resources, as well as mistrust [96]. In addition, there is a particular influence of multinational buyers, including transnational cocoa processing companies and other private off takers, who often place their buying centres in villages and next to cooperatives in order to take control over the local purchases. In some cases, the managers or staff of cooperatives are closely linked to the agents of the multinational corporations, which organize their certification training programs through the cooperatives [98]. Such dynamics tend to weaken the independencies and self-emancipatory function of cooperatives, thus not only limiting their role to marketing, but also undermining their contribution to social cohesion. Besides such external encroachments, cooperatives in Côte d'Ivoire are often also internally divided. Several cases are reported where cooperative elites capture a large share of certification premiums or where scales are biased. However, if they are in independent operation, there is evidence suggesting that cooperatives positively affect the income, health, and well-being of member farmers [99]. Calkins and Ngo [99] observe that these effects may spread to surrounding areas, thus strengthening communities by becoming local service providers where the public sector may be lacking. In Côte d'Ivoire, many companies target these farmers with affiliations to a cooperative or establish new links, excluding a large number of farmers from access to finance and other support, such as training and inputs [100]. However, the alignment of cooperatives' activities with the expectation of external actors, such as multinational corporations or certification organizations, comes with the risk of creating strong dependencies of cooperatives on external resources and the audit of requirements. This in turn might rather limit the potential of cooperatives to act as catalyst of social cohesion among cocoa farmers. Some organizations, such as the Rainforest Alliance, are exploring ways to reach unorganized farmers, for example through traditional community authorities, local government, and existing initiatives [101].

Other collective natural resource management mechanisms that could contribute to social cohesion by strengthening communities and building social capital are REDD+ Local Committees for the Co-Management of Classified Forests (Comités Locaux de Co-Gestion: CLCGs). While not cooperatives, these committees provide a participatory governance structure for local communities to co-manage classified forests, specifically with the establishment of agroforestry concessions and cocoa cooperatives to facilitate the flow of information and finance [102].

However, it must be taken into consideration that the ethnic and regional tensions are also embedded and retrieved in local organizations such as farmer groups, so that these may not be able to appease the situation at a meso-level beyond their local, cohesive membership. Even the contrary is possible, since they may become part of the political conflicts [103]. Hence, the positive contribution of cocoa producers' cooperatives in Côte $\mathrm{d}^{\prime}$ Ivoire to social cohesion and peacebuilding would require a number of more deep-rooted changes that would allow them to unleash their potential. Among others, educational offers on strong management of cooperatives in order to avoid internal mismanagement or some sort of financial startup capital to overcome resource dependencies from multinational corporations could be some first entry points.

\subsection{National Agricultural and Price Policies}

National agricultural and price policies impact social cohesion particularly with the regards to the socio-economic dimension. Although cocoa production is at an all-time high globally and demand is expected to grow further, the chocolate market is subject to constant fluctuation putting the income of farmers at high risk [49]. Price volatility is caused by changing consumer demand, speculative buyers, the dollar price, energy costs, protective measures in terms of market closures of relevant partners, the political situation in producing countries, weather conditions, and the risk of plant diseases [51]. In 2016 and 2017, cocoa prices dropped by 30-40\%, cutting producing farmers' incomes substantially $[49,51,104]$. Thus, some major exporting states seek to implement policies that stabilize the market price. However, such policies also have the potential to destabilize markets as political definitions often fail in expressing real market prices considering 
the underlying actual economic structures. Therefore, their effects need to be monitored carefully. In 2019, the governments of Côte d'Ivoire and Ghana introduced a fixed bulk price for the 2020-2021 cocoa crop as well as a living-income differential that is sought to lift cocoa farmers' earnings and to buffer effects of price volatility for them. Former international attempts to stabilise the cocoa price had failed, though, since conflicts of interest of competing countries and lack of strong control counteracted joined action [105,106]. Zero-deforestation policies will probably affect production costs and could provide premium prices to farmers who comply with its requirements but could squeeze those farmers out of the markets of the Global North who are not able to prove compliance.

\subsubsection{Colombia}

In Colombia, the government shapes the cocoa sector by seeking to establish a stable market structure and by promoting cocoa as an alternative to the cultivation of illicit crops. In fact, the national programme for voluntary substitution of illicit crops incentivises primary producers to shift from coca plants to cocoa cultivars [107]. These incentives include soft credits, capacity-building, and off-farm income during the first years of cocoa cultivation. The rationale behind this strategy is that rural places under pressure of illicit cropping are prone to generate violence and displacement, as well as environmental degradation. International organizations also regard the promotion of diversified cocoa farming systems as an important mechanism to tackle issues related to (1) deforestation and climate change mitigation, (2) circuits of violence, and (3) food insecurity [108]. Since, the cocoa sector has not been involved directly in the armed conflict, or it has not had major conflicts within its value chain development; it has a great potential to foster social cohesion at the community level as a promising cash crop that fits well in the agroforestry culture of the country, contributing also to the development of economic alternatives in the post-conflict. It becomes clear that national agricultural policies have a major role to play in providing best conditions of a sound rural development that enables the rural society to thrive. A meaningful institutional support that brings visible improvements to the rural population would also foster important aspects of vertical and horizontal social cohesion, as, for instance, attitudes of trust in national institutions, an improved sense of identification with the country and, if the prevailing patterns of unfair access to land and services are reduced, improved equality between society members. All of this, in turn, strongly fosters peacebuilding in the post-conflict situation.

\subsubsection{Côte d'Ivoire}

After the cocoa sector was liberalized in 1999, the Ivorian government launched new reforms in 2011 to re-regulate the sector, with the Conseil du Café-Cacao (CCC) responsible for the management, regulation, development, and price stabilisation of cocoa. The reforms were promoted as a way to raise and guarantee minimum farm-gate prices on a sustainable basis, boost output, and apply stricter controls to bean quality. The CCC now allocates export-licences that exporters can buy in auctions. During these auctions, about $70 \%$ to $80 \%$ of the coming year's expected crop are sold to exporters. Ivorian cocoa producers typically sell their unprocessed cocoa beans through local buyers (pisteurs) or farmer cooperatives [97]. Since the 2011 reforms, the producer price is fixed by the government, which means that farmers cannot negotiate prices and prices cannot vary based on quality-although premium payments for certified cocoa are possible. In theory, fixed annual prices are a guarantee to producers, regardless of market movements within the year. In practice, however, Ivorian cocoa farmers receive some of the lowest prices in the world; amongst several factors are the high government taxes on producers. How taxes from cocoa are being used and how that translates into benefits for farmers is not transparently reported. There are recurring reports about corruption, misuse of funds, and further disorganization of the sector due to government interventions [97]. Foreign currency earnings received by the Ivorian Government through high taxation of the cocoa sector are not sufficiently re-invested in the cocoa growing regions. Regular protests by farmer 
organizations demand financial accountability of the state marketing authority. In 2019, Côte d'Ivoire and Ghana formed COPEC [109-111]. Therewith, they introduced the Living Income Differential (LID) programme, which levies an extra fee of $\$ 400$ to the world market price for cocoa [112]. LID was introduced in order to lift cocoa farmers in the two countries out of poverty. The programme to raise the floor price of cocoa has been broadly welcomed by civil society organizations, which highlighted that the premium would not even be high enough [113]. However, the effects of this price measure are not quite clear yet and, up until now, there has been a lack of transparency of how the two governments employ the additional incomes.

\subsection{Certification Schemes}

Over the past decade, sustainability certification schemes became a major approach to address challenges of sustainability and transparency, as well as to improve income opportunities through added value in the cocoa value chain. In principle, there are a variety of certification schemes - some supported by governments, others by private companies — each specifically defined for certain branches or products or designed to generally address due diligence [114]. Membership is voluntary in some cases and mandatory in others. Consumers are increasingly concerned with ethical and environmental grievances in cocoa production, which is why transparency throughout the value chain is increasingly important [115].

Prominent examples for product-specific and voluntary certification in the cocoa sector are Rainforest Alliance (merged with UTZ), Fairtrade, or Organic, whereby Rainforest Alliance accounts for the lion share of certified cocoa beans. The main idea is to set certain production standards, in particular on "good agricultural practices", but also environmental and social welfare standards, and creating a financial incentive for farmers to apply them. Key to the programs is the conduct of farmer field schools, hence training and knowledge transfer. The adaption of the standard is supposed to translate into income increase which in turn should boost farmers' livelihoods. The percentage of so-called voluntary sustainability standards (VSS) has been gradually increasing since its initial implementation more than twenty years ago. In 2016, VSS-compliant products accounted for around $30 \%$ of the total cocoa production. The International Institute for Sustainable Development observes a concentration of VSS-compliant cocoa production in West Africa and includes Côte d'Ivoire on its list of so-called 'Low Human Development Countries' (LHDCs) with the most potential for maximizing sustainable development outcomes [49].

Nevertheless, given limited empirical evidence, there are doubts regarding the actual impacts and significant benefits of sustainability certification schemes [116]. Certification schemes often have limitations in terms of guaranteeing access to the most marginal producers. For instance, acquiring and maintaining diverse formats of organic certification is found to be too costly for small-scale producers, posing significant access barriers for farmers. At the same time, this depends very much on set ups; for example, the benefits for individual farmers also depend on how premiums are spent by the certificate holders (cooperatives or companies). Moreover, in many cases, cocoa sustainability certification schemes are implemented by transnational corporations from the cocoa-chocolate chain and the farmers' role is limited to comply with standards [117]. In acknowledgement of such limitations of third-party certification, alternative schemes have been formulated, such as Participatory Guarantee Systems (PGS), which are gaining momentum in the Global South. As such, PGS advance a methodology of self-managed certification based on principles of relationship-building, mutual learning, trust, context-specificity, local control, diversity, and collective action [118].

\subsubsection{Colombia}

Fluck [119] finds that certification schemes and buyer-supplier relationship-building are important for establishing fair and sustainable trading conditions in the Colombian cocoa sector. Colombia's experience with organic certification began in the coffee sector in the late 1980s. The increase of organic certification is promoted by entities such 
as the Colombian Coffee Growers Federation, to which the vast majority of farmers belong [120]. Although Colombia maintains much of its production of both cocoa and coffee under agroforestry management in traditional multi-strata shaded systems, which are agroecological by default and minimally use of external inputs, certification for these well-kept practices remains low to date ( 914 ha Fairtrade and 350 ha Organic, standardsmap.org) [121]. The promises of a price premium represent the main incentive for many farmers to participate in the program [122]. Nevertheless, as the supply of certified highquality produce from ever more regions enters the global markets, the economic incentive becomes substantially reduced over time [122].

The potential to enhance social cohesion through certification schemes in Colombia will most likely depend on the configuration of actors. On the one hand, direct relations between buyers and suppliers may enhance the sensitivity of buyers to care for conditions of suppliers and initiate partnerships to the real benefit of producers. On the other hand, under conditions of strong asymmetries in the global cocoa-chocolate chain, the entry of powerful buyers at the local level may contain the risk of creating new dependencies which may undermine social cohesion.

\subsubsection{Côte d'Ivoire}

Although a number of impact assessments on certification schemes for the West African cocoa sector have been carried out [123-126], the real impact of certification schemes on cocoa farmers, their livelihoods, and their cocoa farming practices is still contested and studies arrive at differing conclusions. Ingram et al. [127] studied the impact of the UTZ certification for cocoa in Côte d'Ivoire and reflect on the effect of the UTZ code of conduct in the context of numerous challenges such as low productivity. They conclude that the program raised the incomes of 44,000 farmers and that it succeeded in improving the knowledge and implementation of good agricultural practices. Paschall and Seville [101] observe some improved social outcomes, such as school attendance, water access, and engagement in community projects, in Rainforest Alliance/SAN certified farms with possible spillover effects to non-certified farms. However, key program objective is on the increase of farmers' productivity and thus focuses on the practices of farm management and post- harvest handling. At the same time social and environmental aspects tend to be marginalized. Though certification is said to have improved working conditions for farm labourers and contributed to increased awareness of child labour laws and rights, both remain a key issue [100]. A similar observation is made by Lemeilleur, $\mathrm{N}^{\prime}$ Dao, and Ruf [128] who find that criteria addressing productivity issues are prioritized over environmental and social issues when studying the case of the implementation of Rainforest Alliance standards in Côte d'Ivoire. They argue that certification in the name of sustainability is mainly perceived as a productivity-enhancing tool.

Even though focus is on enhancing productivity and the total share of cocoa farmers certified by the major cocoa standards of Rainforest Alliance/SAN and UTZ (now merged to Rainforest Alliance), and Fairtrade has increased in the past years, certified cocoa farmers remain poor [51,129]. In Côte d'Ivoire, the local level implementation of the certification requirements is often done by cooperatives and the premium benefits to individual farmers from certification may actually be quite low as they are mainly used to cover the costs of certification [24]. Women also often have less access to certification and participate less in farmers' organization, extension services, finance, and land rights [51].

The impact of the new generation of value chain laws on main sustainability challenges remains to be seen. Local farmers already struggle to profit from voluntary schemes which are all supported by existing industry partners up the value chains, and which all promise price premia and of the classification of Côte d'Ivoire as LDC. Following from this, one might expect that the poorest farmers and the country as a whole will have even bigger problems in complying with the new requirements from value chain laws which even come without price premia. In the long run, this might even lead to a situation where 
they find themselves squeezed out in benefit of less risky sources such as Colombia or nonconflict-laden-cocoa-producers such as Indonesia.

However, while sustainability certification has the potential to positively affect social cohesion in targeted communities, by providing opportunity for productivity and income gains for cocoa farmers, more structural effects on the local sector constellation need to be studied in order to understand if and how certification could best contribute to strengthening social cohesion. It is possible, for example, that locally backed Participatory Guarantee Systems will show more positive effects since they are driven by territorial actors and therefore consolidate important elements of social cohesion such as trust in local institutions, community cooperation, and solidarity.

\section{Discussion}

With our first research question we asked about the theoretical interlinkages between social cohesion, natural resource management, and peacebuilding. We found that these interlinkages are potentially complex and multidirectional, but together they help to clarify how NRM practices can contribute to peacebuilding process: Social cohesion potentially plays a major role here as a binding element between the two. Thereby, we also facilitate a clarification of the emerging concept of "Environmental peacebuilding", as this assumes that collective NRM holds opportunities for strengthening cooperation and trust- two key ingredients of social cohesion-that ultimately contribute to peacebuilding $[4,16]$.

Social cohesion plays an important role in the development discourse. It is a multidimensional concept that works at different levels reflecting the level of connectedness, interpersonal trust, and reciprocity within a social group. The concept describes the horizontal dimension (relationships among individuals of the same group or across groups, but also among communities and civil society organizations) while the vertical dimension describes the relationships between state and society. Constitutive elements are mutual trust, a sense of belonging, willingness to cooperate and civil political participation. These informal institutions are central to maintaining cooperation in social units and avoiding their disintegration and are complemented by more formal institutions such as norms of behavior, codes of conduct, conventions, laws, and public policies. Socio-economic inequalities are likely to undermine social cohesion. Therefore, achieving distributional justice is often closely linked to social cohesion.

Regarding the second research question, where we asked for the potential of selected key action areas in the context of natural resource management to strengthen social cohesion, we have identified a range of possibilities and opportunities. We investigated these practices to see how successful they could be in fostering social cohesion and therefore have the potential to actively support peacebuilding, using the cocoa production in Colombia and Côte d'Ivoire as examples. In the following, we recapitulate briefly how these four NRM action areas might impact social cohesion with a chance to facilitate peace-building. This might be achieved at either the horizontal dimension-e.g., through reducing inequalities (as a conflict driver) and building social trust—or the vertical dimension, through establishing trust in political institutions and the identification of individuals with a larger community or even nationality.

In order to assess their potential to enhance social cohesion and to support peacebuilding, one should look at the actors which are involved in each of the four action areas discussed above. In the first example, agroforestry potentially increases social cohesion at the horizontal level by reducing inequalities and fostering social relations, creating new links between rural actor groups such as farmers, informal social networks, and local communities. In some cases, it may even help to bridge the gap between indigenous and migrant farmers, as they develop common interests by adopting the same agroforestry practices. It can create new links between rural actor groups, generating employment, and, thus, reducing rural migration and poverty. The involvement of local communities within agroforestry extension services beyond facilitating knowledge transfer, can help increase social proximity among farmers as well as strengthen informal networks as by-product of training 
and education programs. Increased social cohesion can emanate as byproduct from these efforts. Often, state actors are also involved, such as national development organizations which manage and coordinate these programs. This provides a chance to increase trust in institutions, thereby strengthening social cohesion at the vertical dimension. However, where tree planting activities-particularly in frontier-economies-constitute a claim to land ownership, the practice may be linked to local or gender-related land conflicts, and care has to be taken that promoting of tree planting does not create new conflict lines.

Cooperatives, as such, when functional, may be seen as institutionalized forms of social cooperation, in a way an embodiment of social cohesion. The individual members are smallholders and groups of farmers who organize to use economies of scale to their advantage. They increase farmers' bargaining power towards buyers such as multinational corporations, including transnational cocoa processing companies. In some cases, cooperatives can provide public goods to rural communities when state support is absent, creating local networks of support. Thus, cooperatives are a working expression of social cohesion, mainly at the horizontal dimension. Often, they work together with NGOs and civil society, traditional community authorities and local governments. However, as has been shown with the Ivorian case, often the functionality of cooperatives may be limited due to poor management, a lack of funding and resources, as well as mistrust and capture of the organization, so that benefits and increased revenues do not reach the organized farmers. In addition, cooperatives and other farmer organisations may be part of or torn into larger societal conflicts such as ethnic tensions, and then become part of the conflict problem at that inter-institutional level. Following this, the pure existence of cooperatives may not be enough to conclude that social cohesion is achieved; a detailed analysis of the situation is necessary to understand how the full potential of cooperatives to foster social cohesion and empower small-scale farmers can be unfolded.

Agriculture and price policies may be used by exporting states to stabilize the market price and to provide some form of income security for cocoa farmers. State agencies such as the Conseil du Café-Cacao (CCC) thus regulate the relationship between exporters and local buyers (pisteurs) or farmer cooperatives. For this intervention to foster social cohesion, transparency and monitoring of the accurate use will be particularly important. If the positive price effects would not trigger down to the main target group, the cocoa farmers, there is the risk that discontent spreads with a negative effect on institutional trust and vertical social cohesion. Vice versa, if improvements are experienced and real income gains are achieved for cocoa farmers, this could have a positive impact not only on the socio-economic situation of farmers but also on their trust in the national support and foster identification with them. However, such market interventions always bear the risks of policy not appropriately reflecting actual market factors and thereby should be monitored carefully in their effects.

Certification schemes, some supported by governments, others by private companies, also have an international, if not global, dimension, encompassing the cocoa farmers, cooperatives, local authorities, traders, multinational corporations, retailers, and, finally, the consumers. Certification, as such, is a procedure used to institutionalize trust in the production of cocoa and its adherence to product quality and health as well as social and environmental standards. For a long time, consumers mostly have been concerned with their own health and safety for which early certification schemes have been built, but are increasingly concerned with ethical and environmental grievances in cocoa production and fate of local farmers. This may be interpreted as loose form of solidarity and a fluid form of social cohesion operating at a transnational scale. However, the positive effects on social cohesion will again depend heavily on how the principles are put into practice and who the actual beneficiaries are. If the farmers' role is limited to comply with standards and increased revenues do not go beyond what is needed to achieve these standards, success at the local level will remain limited. The same ambivalence holds for the new value chain laws, which, to become fruitful for the lowest income farmers and weaker 
countries, must be accompanied by support measures such as training, advisory services, direct support and long transitional periods.

Certainly, the four action areas discussed here are not solely important in this context.

For example, practices to control the price of cocoa for international buyers are not limited to the national level, but extent to international regimes such as the newly established COPEC ( $a$ 'chocolate OPEC'). If successful, these state-led practices have the potential to foster political and institutional trust and vertical social cohesion, as a consequence. However, the opposite is also possible if these practices fail to benefit farmers and local communities. Lessons are to be learnt from past-mostly failed, except for OPEC-international commodity agreements. They existed in the past as well for cocoa and are disciplined by WTO rules, as they as well influence international trade and can burden competing countries not being members if such agreements $[130,131]$.

In addition, as the dominant market, EU trade policies may support the export of cocoa; however, tariffs are already set to zero for all countries within the bilateral trade agreements with both countries, which provides an advantage compared to other exporters [132]. One relevant trade rule linked to such bilateral tariffs are rules of origin, proving the origin of production, Colombia, for example, and thereby making the product eligible for a defined lower tariff. For processed goods such as chocolate requiring other inputs beside cocoa such as milk, dairy, and nuts, often the origin status becomes difficult if inputs are imported [133]. As a result, higher tariffs may become relevant. A reform of rules of origin towards more processing support in the value chain of chocolate production in the countries producing cocoa, however, is very sensible, both politically, as the EU only bilaterally want to apply preference to the partner and not to other countries providing the inputs, and economically, as the EU processes chocolate to a large extent [59]. However, EU policies also address limitations of the sectors, including restrictions to cocoa beans containing high levels of cadmium, mostly affecting cocoa cultivated in Latin American countries. In addition, new compulsory value chain laws are in the making (EU for social and for deforestation-free chains) or have already been established in several industrialised countries (France, UK, USA, and Germany) [134-139]. They enforce higher social and/or environmental standards for all participants of value chains entering the target markets via due diligence of importing enterprises. They cover diverse topics of particular importance to cocoa, in particular child labor (all) and deforestation (EU). The rigor of control, of due diligence, of rightholders and right claimers, of penalties, and of time to improve the situation or to abandon the sourcing are very different, but it is evident that farmers of different characteristics, and degree and kind of organisation, as well as different countries with different degrees of capabilities and willingness to support their farmers, will be differently affected by these new laws $[134,136]$. The effect of these new legislations on social cohesion at various levels will need to be monitored and discussed once more evidence on their effectiveness can be established.

Finally, it should be noted that the causal direction of the linkages between NRM practices and social cohesion and peacebuilding is not immediately clear and might work both ways. For example, intuitively, peace and social cohesion may also be viewed as a necessary precondition for successful and sustainable natural resource management. We also reiterate that the exact design of and constellation within and across the action areas bears many potentials to improve NRM and social cohesion, but that they can also worsen them-the Côte d'Ivoire study provides an alarming example for the latter. This is because after all, the action areas can accommodate (sets of) institutions aiming at managing the exploitation of NRM, but they cannot make disappear the conflicts of interest of actors involved. The more severe the conflicts are, the more challenging it is to design the action areas in a way leading to peace, sustainability and social cohesion. However, conflicts about land and political power which are found around key agricultural value chains in developing countries often are severe. We argue that these action areas are key levers but not that they automatically lead to overall success. Rather, any effects are bound to be highly context dependent. Indeed, there are many factors linking NRM and peacebuilding, 
from economic development to social cooperation. In this contribution, we focused on one linking factor, namely social cohesion. Thereby, we provide arguments why NRM does not necessarily need to be linked to violence and conflict, as was often thought previously. Still, we emphasize that this study is not an in-depth empirical investigation, but rather a conceptual contribution, in which we draw on selected empirical insights and anecdotal evidence to substantiate and illustrate our argument. It will be the task of empirical research in the future to substantiate which of these possible links actually can be observed in the field.

\section{Conclusions}

This study analysed the nexus of social cohesion, natural resource management, and peacebuilding, concluding that a multi-dimensional, systemic perspective is necessary. Looking at the case studies of Colombia and Côte d'Ivoire, we showed that despite the differences in the two countries, social cohesion in both post-conflict societies can benefit from the tropical high-value natural resource that is cocoa. We therefore argue that sustainable cocoa production in agroforestry systems and adequate natural resource management not only offer the potential to ecological restoration, but also have great potential to promote and consolidate peace as cocoa production provides smallholders with a living and fosters rural development.

However, it is not a one-way street. Certain NRM approaches and tools could potentially contribute but may-if done incorrectly without proper knowledge of the local context-even cause harm or aggravate disparities. A Do-No-Harm approach needs to be mainstreamed with a focus on social cohesion variables, as otherwise desired objectives might not be achieved. Overall, not addressing these social dimensions can undermine the positive effects of planned agricultural development interventions. As a consequence, fostering social cohesion should become a key objective for planning agricultural development interventions in the future in order to move beyond mere productivity measures and to include society-building interventions. Introducing sustainable practices for agricultural production could be part of transitional justice and post-conflict reconstruction mechanisms, which embed restoring social cohesion horizontally and vertically. For example, granting access to land to farmers victims of armed conflict as a compensation measure could be enhanced by giving them access to knowledge, capital, and credits for cocoa cultivation projects. Furthermore, combined initiatives among farmers, victims and former combatants around cocoa cultivation could be seen as a mechanism to foster social cohesion and reconciliation.

Author Contributions: Article Conceptualization, K.L., S.H. and M.W.; Funding acquisition, K.L., S.S., C.U. and M.W.; Investigation, K.L., B.A., D.B., M.B. (Michael Brüntrup), C.B., A.C.-N., G.C.-M., M.L.D.R., S.H., H.C.M.M., F.O., T.R., B.R., J.S., A.S., I.S., S.S., S.T., C.V. and M.W.; Visualization, K.L., M.B. (Michelle Bonatti), S.H., B.R. and M.W.; Writing—original draft, K.L., B.A., D.B., C.B., G.C.-M., M.L.D.R., S.H., H.C.M.M., T.R., B.R., I.S., S.T., C.V. and M.W.; Writing-review \& editing, K.L., M.B. (Michelle Bonatti), M.B. (Michael Brüntrup), C.B., A.C.-N., G.C.-M., S.H., H.C.M.M., F.O., B.R., A.S., I.S., S.S., S.T., C.U., C.V. and M.W. All authors have read and agreed to the published version of the manuscript.

Funding: This research was conducted in the frame of SUSCOCOA project 'Social cohesion in the context of peacebuilding: Exploring the nexus of social cohesion, governance and environmental peacebuilding' funded by the Berlin University Alliance (BUA) in the frame of the Social Cohesion pre-call; grant no GC_SC_PC_13. Open access fees were funded by Leibniz Centre for Agricultural Landscape Research (ZALF).

Institutional Review Board Statement: Not applicable.

Informed Consent Statement: Not applicable.

Acknowledgments: This study is the result of an Expert Forum on Enhancing Social Cohesion through Sustainable Cocoa Production organized in the frame of SUSCOCOA project. Great ap- 
preciation to all the speakers and the audience for the great contributions that helped to advance this study.

Conflicts of Interest: The authors declare no conflict of interest. The funders had no role in the design of the study; in the collection, analyses, or interpretation of data; in the writing of the manuscript, or in the decision to publish the results.

\section{References}

1. Bruch, C.; Jensen, D.; Nakayama, M.; Unruh, J.; Gruby, R.; Wolfarth, R. Post-Conflict Peace Building and Natural Resources. In Yearbook of International Environmental Law; Oxford University Press: Oxford, UK, 2009; Volume 19, pp. 58-96. [CrossRef]

2. Jensen, D.; Brown, O.; Matthew, R. From Conflict to Peacebuilding: The Role of Natural Resources and the Environment; United Nations Environment Programme (UNEP): Nairobi, Kenya, 2009; ISBN 978-92-807-2957-3.

3. Muralikrishna, I.V.; Manickam, V. Chapter Three-Natural Resource Management and Biodiversity Conservation. In Environmental Management; Muralikrishna, I.V., Manickam, V., Eds.; Butterworth-Heinemann: Oxford, UK, 2017; pp. 23-35, ISBN 978-0-12-811989-1.

4. Dresse, A.; Nielsen, J.; Zikos, D. Moving beyond Natural Resources as a Source of Conflict: Exploring the Human-Environment Nexus of Environmental Peacebuilding; THESys Discussion Paper 2016, No. 2016-2; IRI THESys: Berlin, Germany, 2016; pp. 1-22.

5. Harwell, E. Building momentum and constituencies for peace: The role of natural resources in transitional justice and peacebuilding. In Governance, Natural Resources and Post-Conflict Peacebuilding; Routledge: London, UK, 2016; pp. 633-664, ISBN 1136272062.

6. Castro-Nunez, A.; Mertz, O.; Buritica, A.; Sosa, C.C.; Lee, S.T. Land related grievances shape tropical forest-cover in areas affected by armed-conflict. Appl. Geogr. 2017, 85, 39-50. [CrossRef]

7. Ross, M.L. How Do Natural Resources Influence Civil War? Evidence from Thirteen Cases. Int. Organ. 2004, 58, 35-67. [CrossRef]

8. Collier, P.; Hoeffler, A. Greed and grievance in civil war. Oxf. Econ. Pap. 2004, 56, 563-595. [CrossRef]

9. Chan, J.; To, H.-P.; Chan, E. Reconsidering Social Cohesion: Developing a Definition and Analytical Framework for Empirical Research. Soc. Indic. Res. 2006, 75, 273-302. [CrossRef]

10. Berger-Schmitt, R. Considering Social Cohesion in Quality of Life Assessments: Concept and Measurement. Soc. Indic. Res. 2002, 58, 403-428. [CrossRef]

11. Ros-Tonen, M.A.F.; Derkyi, M. Conflict or cooperation? Social capital as a power resource and conflict mitigation strategy in timber operations in Ghana's off-reserve forest areas. Ecol. Soc. 2018, 23, 23. [CrossRef]

12. Ide, T.; Bruch, C.; Carius, A.; Conca, K.; Dabelko, G.D.; Matthew, R.; Weinthal, E. The past and future(s) of environmental peacebuilding. Int. Aff. 2021, 97, 1-16. [CrossRef]

13. Baptiste, B.; Pinedo-Vasquez, M.; Gutierrez-Velez, V.H.; Andrade, G.I.; Vieira, P.; Estupiñán-Suárez, L.M.; Londoño, M.C.; Laurance, W.; Lee, T.M. Greening peace in Colombia. Nat. Ecol. Evol. 2017, 1, 102. [CrossRef]

14. Eufemia, L.; Bonatti, M.; Castro-Nunez, A.; Lana, M.; Morales, H.; Sieber, S. Colombia's inadequate environmental goals. Science 2019, 364, 444-445. [CrossRef] [PubMed]

15. Morales-Muñoz, H.; Löhr, K.; Bonatti, M.; Eufemia, L.; Sieber, S. Assessing impacts of environmental peacebuilding in Caquetá, Colombia: A multistakeholder perspective. Int. Aff. 2021, 97, 179-199. [CrossRef]

16. Bruch, C.; Slobodian, L.; Nichols, S.S.; Muffett, C. Facilitating peace or fueling conflict? Lessons in post-conflict governance and natural resource management. In Governance, Natural Resources, and Post-Conflict Peacebuilding; Routledge: London, UK, 2016 ; pp. 953-1040.

17. Cox, F.D.; Sisk, T.D. Peacebuilding in Deeply Divided Societies: Toward Social Cohesion? Springer: Berlin/Heidelberg, Germany, 2017; ISBN 331950715X.

18. Sisk, T.D. Strengthening Social Cohesion: Conceptual Framing and Programming Implications; United Nations Development Programme: New York, NY, USA, 2020.

19. Lederach, J.P. Building Peace: Sustainable Reconciliation in Divided Societies; United States Institute of Peace Press: Washington, DC, USA, 1997.

20. Pearce, J. Sustainable peace-building in the South: Experiences from Latin America. Dev. Pract. 1997, 7, 438-455. [CrossRef]

21. Galtung, J. Violence, Peace, and Peace Research. J. Peace Res. 1969, 6, 167-191. [CrossRef]

22. Lujala, P.; Rustad, S.A.; Jensen, D.; Crawford, A.; Whitten, P.; Coyle, I.; Bruch, C. Policy Brief 1: High-Value Natural Resources and Post-Conflict Peacebuilding; Routledge: London, UK, 2013.

23. Collier, P.; Hoeffler, A.; Söderbom, M. Post-Conflict Risks. J. Peace Res. 2008, 45, 461-478. [CrossRef]

24. Lujala, P.; Rustad, S. High-value Natural Resources: A Blessing or a Curse for Peace? Sustain. Dev. Law Policy 2012, 12, 19.

25. Humphreys, M. Natural Resources, Conflict, and Conflict Resolution: Uncovering the Mechanisms. J. Confl. Resolut. 2005, 49, 508-537. [CrossRef]

26. Global Witness. Hot Chocolate: How Cocoa Fuelled the Conflict in Cote d'Ivoire; Global Witness: Washington, DC, USA, 2007.

27. UN Secretary-General. Report of the Secretary-General on Peacebuilding in the Immediate Aftermath of Conflict A/63/881S/2009/304. 2009. Available online: https:/ / www.refworld.org/docid/4a4c6c3b2.html (accessed on 9 July 2021).

28. World Bank. World Development Report 2011: Conflict, Security, and Development; The World Bank: Washington, DC, USA, 2011; ISBN 0821384392.

29. Fearon, J.D.; Humphreys, M.; Weinstein, J.M. Can Development Aid Contribute to Social Cohesion after Civil War? Evidence from a Field Experiment in Post-Conflict Liberia. Am. Econ. Rev. Pap. Proc. 2009, 99, 287-291. [CrossRef]

30. Ranci, C. Competitiveness and Social Cohesion in Western European Cities. Urban Stud. 2011, 48, 2789-2804. [CrossRef] 
31. Chavez-Miguel, G.; Löhr, K.; Acevedo-Osorio, A.; Bonatti, M.; Sieber, S. Agroecology as a community-based natural resource management approach for strengthening social cohesion and resilience in post-conflict settings. 2021, unpublished-under revision at GAIA.

32. UNDP. Community Security and Social Cohesion: Towards a UNDP Approach; Bureau for Crisis Prevention and Recovery, UNDP: New York, NY, USA, 2009.

33. Langer, A.; Stewart, F.; Smedts, K.; Demarest, L. Conceptualising and Measuring Social Cohesion in Africa: Towards a PerceptionsBased Index. Soc. Indic. Res. 2017, 131, 321-343. [CrossRef]

34. Cox, F.; Sisk, T. (Eds.) Peacebuilding: A Social Cohesion Approach. In Peacebuilding in Deeply Divided Societies; Springer International Publishing: Cham, Switzerland, 2017; pp. 13-31. ISBN 978-3-319-50714-9.

35. Brown, M.J.; Zahar, M.-J. Social Cohesion as Peacebuilding in the Central African Republic and Beyond. J. Peacebuilding Dev. 2015, 10, 10-24. [CrossRef]

36. King, E.; Samii, C.; Snilstveit, B. Interventions to promote social cohesion in sub-Saharan Africa. J. Dev. Eff. 2010, 2, 336-370. [CrossRef]

37. Benard, S.; Doan, L. The Conflict-Cohesion Hypothesis: Past, Present, and Possible Futures. Adv. Group Process. 2011, 28, 189-225. [CrossRef]

38. Cox, F.D.; Orsborn, C.R.; Sisk, T.D. Religion, Peacebuilding, and Social Cohesion in Conflict-Affected Countries; University of Denver: Denver, CO, USA, 2014.

39. McDonald, P.J. Peace through Trade or Free Trade? J. Confl. Resolut. 2004, 48, 547-572. [CrossRef]

40. Ostrom, E. Governing the Commons: The Evolution of Institutions for Collective Action; Cambridge University Press: Cambridge, UK, 1990.

41. Hardin, G. The Tragedy of the Commons. Science 1968, 162, 1243-1248. [CrossRef] [PubMed]

42. Stockins, P.; Canal Albán, F.; Quiroga Martínez, R.; Rodríguez Aldabe, Y.; Nájera, M. Tendiendo Puentes Entre el Desarrollo Sostenible y la Cohesión Social. In Cohesión Social en América Latina: Una Revisión de Conceptos, Marcos de Referencia e Indicadores; LC/G. 2420; CEPAL: Santiago, Chile, 2010; pp. 109-142.

43. Oviedo, G.; Mansourian, S.; Vallauri, D.; Dudley, N. Land Ownership and Forest Restoration. In Forest Restoration in Landscapes. Beyond Planting Trees; Mansourian, S., Vallauri, D., Dudley, N., Eds.; Springer: New York, NY, USA, 2005; pp. 84-93, ISBN 0-387-25525-7.

44. Rocheleau, D.; Edmunds, D. Women, men and trees: Gender, power and property in forest and agrarian landscapes. World Dev. 1997, 25, 1351-1371. [CrossRef]

45. Castro-Nunez, A.; Charry, A.; Castro-Llanos, F.; Sylvester, J.; Bax, V. Reducing deforestation through value chain interventions in countries emerging from conflict: The case of the Colombian cocoa sector. Appl. Geogr. 2020, 123, 102280. [CrossRef]

46. Shahbandeh, M. Cocoa Production Worldwide from 1980/81 to 2018/19 (in 1000 Tons). Available online: https: / /www.statista. $\mathrm{com} /$ statistics/262620/global-cocoa-production/ (accessed on 16 April 2020).

47. International Cocoa Organization. World Cocoa Bean Production, Grindings, and Stocks. Available online: https://www.icco. $\mathrm{org} /$ statistics/\#top (accessed on 7 October 2021).

48. Institute for Economics \& Peace. Global Peace Index 2019: Measuring Peace in a Complex World; Institute for Economics \& Peace: New York, NY, USA; Sydney, Australia, 2019.

49. Voora, V.; Bermúdez, S.; Larrea, C. Global Market Report: Cocoa; International Institute for Sustainable Development: Winnipeg, MB, Canada, 2019.

50. Martínez Collazos, J. Una mirada al mundo de la agricultura y el desarrollo rural. In La Agricultura Familiar en Colombia. Estudios de Caso Desde la Multifuncionalidad y su Aporte a la Paz; Acevedo-Osorio, Á., Martínez-Collazos, J., Eds.; Ediciones Universidad Cooperativa de Colombia-Corporación Universitaria Minuto de Dios-Agrosolidaria: Bogotá, Colombia, 2016 ; pp. 9-29.

51. Fountain, A.C.; Hütz-Adams, F. Kakao-Barometer 2018. Available online: https://webshop.inkota.de/node/1546 (accessed on 21 September 2021).

52. Franzen, M.; Mulder, M.B. Ecological, economic and social perspectives on cocoa production worldwide. Biodivers. Conserv. 2007, 16, 3835-3849. [CrossRef]

53. Clay, J. World Agriculture and the Environment: A Commodity-by-Commodity Guide to Impacts and Practices; Island Press: Washington, DC, USA, 2013; ISBN 161091015X.

54. Sabas, B.Y.S.; Danmo, K.G.; Madeleine, K.A.T.; Jan, B. Cocoa Production and Forest Dynamics in Ivory Coast from 1985 to 2019. Land 2020, 9, 524. [CrossRef]

55. Trading Economics. Ivory Coast Exports by Category. Available online: https://tradingeconomics.com/ivory-coast/exports-bycategory (accessed on 22 October 2021).

56. OEC. Where Does Cote d'Ivoire Export Cocoa and Cocoa Preparations to? 2019. Available online: https://oec.world/en/ visualize/tree_map/hs92/export/civ/all/418/2019/ (accessed on 22 October 2021).

57. Trading Economics. Colombia Exports by Category. Available online: https://tradingeconomics.com/colombia/exports-bycategory (accessed on 22 October 2021).

58. OEC. Where Does Colombia Export Cocoa and Cocoa Preparations to? 2019. Available online: https://oec.world/en/visualize/ tree_map/hs92/export/col/all/418/2019/ (accessed on 22 October 2021).

59. CBI. What Is the Demand for Cocoa on the European Market? Available online: https://www.cbi.eu/market-information/cocoa/ trade-statistics (accessed on 7 October 2021). 
60. Zomer, R.; Trabucco, A.; Coe, R.; Place, F. Trees on Farm: Analysis of Global Extent and Geographical Patterns of Agroforestry; ICRAF Working Paper; World Agroforestry Centre: Nairobi, Kenya, 2009.

61. Nair, P.K.R.; Garrity, D. Agroforestry-The Future of Global Land Use, 1st ed.; Springer: Dordrecht, The Netherlands, 2012; ISBN 978-94-017-8122-0.

62. Reij, C.; Garrity, D. Scaling up farmer-managed natural regeneration in Africa to restore degraded landscapes. Biotropica 2016, 48, 834-843. [CrossRef]

63. Montes-Londoño, I. Tropical Dry Forests in Multi-functional Landscapes: Agroforestry Systems for Conservation and Livelihoods. In Integrating Landscapes: Agroforestry for Biodiversity Conservation and Food Sovereignty; Springer: Singapore, $2017 ;$ pp. 47-78.

64. Jacobi, J.; Schneider, M.; Bottazzi, P.; Pillco, M.; Calizaya, P.; Rist, S. Agroecosystem resilience and farmers' perceptions of climate change impacts on cocoa farms in Alto Beni, Bolivia. Renew. Agric. Food Syst. 2015, 30, 170-183. [CrossRef]

65. Lasco, R.D.; Delfino, R.J.P.; Catacutan, D.C.; Simelton, E.S.; Wilson, D.M. Climate risk adaptation by smallholder farmers: The roles of trees and agroforestry. Curr. Opin. Environ. Sustain. 2014, 6, 83-88. [CrossRef]

66. Pagiola, S.; Rios, A.R.; Arcenas, A. Poor Household Participation in Payments for Environmental Services: Lessons from the Silvopastoral Project in Quindío, Colombia. Environ. Resour. Econ. 2010, 47, 371-394. [CrossRef]

67. Cerda, R.; Deheuvels, O.; Calvache, D.; Niehaus, L.; Saenz, Y.; Kent, J.; Vilchez, S.; Villota, A.; Martinez, C.; Somarriba, E. Contribution of cocoa agroforestry systems to family income and domestic consumption: Looking toward intensification. Agrofor. Syst. 2014, 88, 957-981. [CrossRef]

68. Jagoret, P.; Kwesseu, J.; Messie, C.; Michel-Dounias, I.; Malézieux, E. Farmers' assessment of the use value of agrobiodiversity in complex cocoa agroforestry systems in central Cameroon. Agrofor. Syst. 2014, 88, 983-1000. [CrossRef]

69. Ruf, F.O. The Myth of Complex Cocoa Agroforests: The Case of Ghana. Hum. Ecol. 2011, 39, 373-388. [CrossRef]

70. Lujala, P.; Rustad, S.A.; Kettenmann, S. Engines for Peace? Extractive Industries, Host Countries, and the International Community in Post-Conflict Peacebuilding. Nat. Resour. 2016, 7, 239-250. [CrossRef]

71. Zinngrebe, Y.; Borasino, E.; Chiputwa, B.; Dobie, P.; Garcia, E.; Gassner, A.; Kihumuro, P.; Komarudin, H.; Liswanti, N.; Makui, P.; et al. Agroforestry governance for operationalising the landscape approach: Connecting conservation and farming actors. Sustain. Sci. 2020, 15, 1417-1434. [CrossRef]

72. Isaac, M.E.; Erickson, B.H.; Quashie-Sam, S.J.; Timmer, V.R. Transfer of Knowledge on Agroforestry Management Practices: The Structure of Farmer Advice Networks. Ecol. Soc. 2007, 12, 32. [CrossRef]

73. David, S.; Asamoah, C. The Impact of Farmer Field Schools on Human and Social Capital: A Case Study from Ghana. J. Agric. Educ. Ext. 2011, 17, 239-252. [CrossRef]

74. Cocoa and Forests Initiative. Cocoa, Forests and Peace Initiative in Colombia: Joint Framework for Action; Cocoa \& Forests Initiative: Bogotá, Colombia, 2018. Available online: https:/ /www.worldcocoafoundation.org/wp-content/uploads/2018/08/ColombiaCocoa-Forests-and-Peace-Initiative-Joint-Framework-for-Action-English.pdf (accessed on 20 November 2021).

75. Davey, E. How Cocoa Farming Can Preserve Forests and Peace in Colombia; World Resources Institute: Washington, DC, USA, 2018.

76. Meyfroidt, P.; Lambin, E.F.; Erb, K.; Hertel, T.W. Globalization of land use: Distant drivers of land change and geographic displacement of land use. Curr. Opin. Environ. Sustain. 2013, 5, 438-444. [CrossRef]

77. Cocoa \& Forests Initiative; World Cocoa Foundation. Summary of Company Initial Action Plans for Côte d'Ivoire. Available online: https:/ / www.worldcocoafoundation.org/wp-content/uploads/2018/08/CFI-Aggregate-Action-Plan-CdI-02.28.19.pdf (accessed on 20 November 2021).

78. Vanegas, C. 2030 Action Plan for the Cocoa, Forests and Peace Initiative in Colombia; IDH, The Sustainable Trade Initiative: Utrecht, The Netherlands, 2019.

79. Iniciativa Cacao Bosques \& Paz Colombia. Plan de Acción Cacao, Bosques \& Paz 2020-2030. Available online: https: / cacaobp org/plan-de-accion-2020-2030/\#pll_switcher (accessed on 20 November 2021).

80. Abbott, P.C.; Benjamin, T.J.; Burniske, G.R.; Croft, M.M.; Fenton, M.; Kelly, C.R.; Lundy, M.; Rodriguez Camayo, F.; Wilcox, M.D. An Analysis of the Supply Chain of Cacao in Colombia; United States Agency for International Development-USAID: Cali, CO, USA, 2018.

81. Ruf, F. Cocoa combined with palm wine in Côte d'Ivoire: An unexpected resilience. Bois Forets Trop. 2014, 321, 33. [CrossRef]

82. Chauveau, J.-P.; Colin, J.-P. Customary Transfers and Land Sales in Côte d'Ivoire: Revisiting the Embeddedness Issue. Africa 2010, 80, 81-103. [CrossRef]

83. Grajales, J. Losing land in times of peace: Post-war agrarian capitalism in Colombia and Côte d'Ivoire Colombia and Côte d'Ivoire. J. Peasant. Stud. 2020, 48, 1054-1074. [CrossRef]

84. Mitchell, M.I. Insights from the cocoa regions in Côte d'Ivoire and Ghana: Rethinking the migration-conflict nexus. Afr. Stud. Rev. 2011, 54, 123-144. [CrossRef]

85. Boone, C. Shifting visions of property under competing political regimes: Changing uses of Côte d'Ivoire's 1998 Land Law. J. Mod. Afr. Stud. 2018, 56, 189-216. [CrossRef]

86. Thomson, A.; König, S.; Bakhtary, H.; Young, K.J. Developing Cocoa Agroforestry Systems in Ghana and Côte d'Ivoire; Climate Focus North America: Washington, DC, USA, 2020; Available online: https://www.climatefocus.com/sites/default/files/Developing\% 20Cocoa\%20Agroforesty\%20Systems\%20in\%20Ghana\%20and\%20Cote\%20d\%27Ivoire.pdf (accessed on 20 November 2021).

87. Sanial, E.; Ruf, F. Is kola Tree the Enemy of Cocoa? A Critical Analysis of Agroforestry Recommendations Made to Ivorian Cocoa Farmers. Hum. Ecol. 2018, 46, 159-170. [CrossRef] 
88. Sanial, E.; Fountain, A.C.; Hoefsloot, H.; Jezeer, R. Agroforestry in the Cocoa Sector-A Need for Ambitious Collaborative Landscape Approaches. The Cocoa Barometer Consortium 2020. Available online: https://www.tropenbos.org/file.php/2345/2 9072020-consultation-paper-2020.pdf (accessed on 20 November 2021).

89. Ruf, F.; Schroth, G.; Doffangui, K. Climate change, cocoa migrations and deforestation in West Africa: What does the past tell us about the future? Sustain. Sci. 2015, 10, 101-111. [CrossRef]

90. Gizèle, Z.G.; Bruno, K.K.; Sabas, B.Y.S.; Jan, B. Migration and Agricultural Practices in the Peripheral Areas of Côte d'Ivoire State-Owned Forests. Sustainability 2019, 11, 6378. [CrossRef]

91. International Co-Operative Alliance. International Co-Operative Alliance-Annual Report; International Co-Operative Alliance: Geneva, Switzerland, 2005.

92. Gutiérrez, J.D. Smallholders' Agricultural Cooperatives in Colombia: ¿Vehicles for Rural Development? Rev. Desarro. Soc. 2014, 219-271. [CrossRef]

93. Botero Usquiano, C.L.; Carvajal Rojas, D.C. Análisis del Impacto del Modelo Cooperativo Como Alternativa de Desarrollo Humano de los Agricultores Asociados a la Cooperativa Cipaotanche del Municipio de Otanche en el Occidente de Boyacá 2017. Available online: https:/ / ciencia.lasalle.edu.co/cgi/viewcontent.cgi?article=1124\&context=maest_gestion_desarrollo (accessed on 20 November 2021).

94. Government of Colombia. Hacia un Nuevo Campo Colombiano: Reforma Rural Integral. Available online: https://www. peaceagreements.org/wview /817/Hacia\%20un\%20Nuevo \%20Campo\%20Colombiano:\%20Reforma\%20Rural\%20Integral (accessed on 19 November 2021).

95. Confecoop. Informe de Desempeño. 2018. Available online: https://confecoop.coop/wp-content/uploads/2019/12/INFORME2018.pdf (accessed on 15 January 2020).

96. Gefak. Study on the State of Farmer Cooperatives in the Cocoa Sector of Côte d'Ivoire: Draft Final Report; Gefak: Liestal, Switzerland, 2015.

97. Bymolt, R.; Laven, A.; Tyzler, M. Demystifying the Cocoa Sector in Ghana and Côte d'Ivoire; The Royal Tropical Institute (KIT): Amsterdam, The Netherlands, 2018.

98. Ruf, F.; Kiendré, J.; Galo, A.; Konan, A.G.P. Les Coopératives Cacao de Côte d'Ivoire au Milieu du Marigot. Available online: https://www.tdc-enabel.be/fr/2020/12/17/les-cooperatives-cacao-de-cote-divoire-au-milieu-du-marigot/ (accessed on 11 August 2021).

99. Calkins, P.; Ngo, A.-T. The Impacts of Farmer Cooperatives on the Well-Being of Cocoa Producing Villages in Côte d'Ivoire and Ghana. Can. J. Dev. Stud. 2010, 30, 535-563. [CrossRef]

100. Ingram, V.; van Rijn, F.; Waarts, Y.; Dekkers, M.; de Vos, B.; Koster, T.; Tanoh, R.; Galo, A. Towards Sustainable Cocoa in Côte d’Ivoire: The Impacts and Contribution of UTZ Certification Combined with Services Provided by Companies; Wageningen Economic Research: Wageningen, The Netherlands, 2018; ISBN 9789463437769.

101. Paschall, M.; Seville, D. Certified Cocoa: Scaling up Farmer Participation in West Africa; Case Study Series, New Business Models for Sustainable Trading Relationships; International Institute for Environment and Development (IIED): London, UK, 2012 ; p. 28. Available online: https:/ / pubs.iied.org/sites/default/files/pdfs/migrate/16034IIED.pdf (accessed on 20 November 2021).

102. Forest Carbon Partnership Facility (FCPF) Carbon Fund. Emissions Reduction Program Document for Taï National Park, Republic of Côte d'Ivoire; World Bank: Washington, DC, USA, 2019.

103. Chauveau, J.-P. The Land Tenure Question in Côte d'Ivoire: A Lesson in History; International Institute for Environment and Development, Drylands Programme: London, UK, 2000.

104. ICCO. The World Cocoa Economy: Past and Present; ICCO: Phnom Penh, Cambodia, 2012.

105. Hanisch, R. Kakaopolitik. Das Ringen der Entwicklungsländer um die Regulierung eines Rohstoffmarktes. Verfass. Recht Übersee 1978, 11, 27-57. [CrossRef]

106. Michaelowa, K.; Naini, A. Der Gemeinsame Fonds und Die Speziellen Rohstoffabkommen: Studie im Auftrag des Bundesministerium für Wirtschaft, 1st ed.; Nomos-Verlag-Ges: Baden-Baden, Germany, 1995; ISBN 978-3-7890-3702-3.

107. Sierra, D.C. El Cacao Como Producto Lider en la Substitution de Cultivos Ilicitos en el Proceso de Posconflicto; Facultad de Relaciones Internacionales, Estrategia y Seguridad Programa de Relaciones Internacionales y Estudios Politicos, Universidad Militar Nueva Granada: Bogotá, Colombia, 2016.

108. Fontecha-Tirado, M.M. Building Trust and Collaborating with Others: Challenges for a Sustainable Peace in Caquetá, Colombia. Consilience 2018, 19, 163-183.

109. Wexler, A. Cocoa Cartel Stirs up Global Chocolate Market. Wall Str. J. 2020. Available online: https://www.wsj.com/articles/ new-cocoa-cartel-could-overhaul-global-chocolate-industry-11578261601 (accessed on 20 November 2021).

110. Gifford, C. Sweet Nothings: What West Africa's COPEC Plan Means for Cocoa Farmers. World Finance, 10 April 2020. Available online: https:/ / www.worldfinance.com/markets/sweet-nothings-what-west-africas-copec-plan-means-for-cocoafarmers(accessed on 9 July 2021).

111. Schwarz, E. How Hershey Kisses and COPEC Are Like Oil and OPEC [Online]. Available online: https://econlife.com/2020/01/ higher-cocoa-bean-prices/ (accessed on 24 April 2020).

112. Odijie, M.E. Why Efforts by Côte d'Ivoire and Ghana to Help Cocoa Farmers Haven't Worked. Available online: https: //theconversation.com/why-efforts-by-cote-divoire-and-ghana-to-help-cocoa-farmers-havent-worked-162845 (accessed on 7 October 2021). 
113. Voice Network. A Watchdog and Catalyst for a Reformed Cococa Sector. Available online: https://www.voicenetwork.eu/ (accessed on 7 October 2021).

114. Rudloff, B.; Wieck, C. Sustainable Supply Chains in the Agricultural Sector; Stiftung Wissenschaft und Politik.: Berlin, Germany, 2020.

115. Gockowski, J.; Afari-Sefa, V.; Sarpong, D.B.; Osei-Asare, Y.B.; Agyeman, N.F. Improving the productivity and income of Ghanaian cocoa farmers while maintaining environmental services: What role for certification? Int. J. Agric. Sustain. 2013, 11, 331-346. [CrossRef]

116. Blackman, A.; Rivera, J.E. The Evidence Base for Environmental and Socioeconomic Impacts of 'Sustainable' Certification; RFF-DP 10-17; Resources for the Future (RFF): Washington, DC, USA, 2010. Available online: https://media.rff.org/documents/RFF-DP-10-17. pdf (accessed on 20 November 2021).

117. Ollendorf, F. Corporate Social Responsibility in the Global Cocoa Chocolate Chain-Insights from sustainability certification in Ghana's cocoa communities. In Global Commodity Chains and Labor Relations; Komlosy, A., Music, G., Eds.; Brill: Leiden, The Netherlands; Boston, MA, USA, 2021; ISBN 978-90-04-44803-2.

118. Nelson, E.; Tovar, L.G.; Gueguen, E.; Humphries, S.; Landman, K.; Rinderman, R.S. Participatory guarantee systems and the re-imagining of Mexico's organic sector. Agric. Hum. Values 2016, 33, 373-388. [CrossRef]

119. Fluck, C. Closing the Gap between the Current and Potential Conditions in the Cocoa (Production) Industry: Comparing Colombia and Mexico; University of Twente: Enschede, The Netherlands; Available online: https://essay.utwente.nl/66299/1/Fluck\%20 Caroline_BA_MB.pdf (accessed on 20 November 2021).

120. Ibanez, M.; Blackman, A. Is Eco-Certification a Win-Win for Developing Country Agriculture? Organic Coffee Certification in Colombia. World Dev. 2016, 82, 14-27. [CrossRef]

121. International Trade Centre, Standards Map. The State of Sustainable Markets-2020. Available online: https://standardsmap. org/trends (accessed on 11 August 2021).

122. Rueda, X.; Lambin, E.F. Responding to Globalization: Impacts of Certification on Colombian Small-Scale Coffee Growers. Ecol. Soc. 2013, 18, 18. [CrossRef]

123. Waarts, Y.R.; Ingram, V.J.; Linderhof, V.G.M.; Puister-Jansen, L.F.; van Rijn, F.C.; Aryeetey, R. Impact of UTZ Certification on Cocoa Producers in Ghana, 2011 to 2014; LEI Report 2015-066 (44 pp); LEI Wageningen UR (University \& Research Centre): Den Haag, The Netherlands, 2015; ISBN 9789086157150.

124. Fenger, N.A.; Bosselmann, A.S.; Asare, R.; de Neergaard, A. The impact of certification on the natural and financial capitals of Ghanaian cocoa farmers. Agroecol. Sustain. Food Syst. 2017, 41, 143-166. [CrossRef]

125. Bethge, J.P. Sustainability Certification: Comparative Analysis of Different Approaches, Their Implementation and Impacts Using the Examples of Fairtrade and Rainforest Alliance in the Cocoa Sector of Ghana; LIT Verlag Münster: Münster, Germany, 2014; ISBN 3643903960.

126. Ingram, V.; Van Rijn, F.; Waarts, Y.; Gilhuis, H. The Impacts of Cocoa Sustainability Initiatives in West Africa. Sustainability 2018, 10, 4249. [CrossRef]

127. Ingram, V.J.; Waarts, Y.R.; Ge, L.; van Vugt, S.M.; Wegner, L.; Puister-Jansen, L.F. Impact of UTZ Certification of Cocoa in Ivory Coast. Assessment Framework and Baseline; LEI Reports 2014-010; LEI Wageningen UR: Den Haag, The Netherlands, 2014; I.S.B.N.9789086156764.

128. Lemeilleur, S.; N'Dao, Y.; Ruf, F. The productivist rationality behind a sustainable certification process: Evidence from the Rainforest Alliance in the Ivorian cocoa sector. Int. J. Sustain. Dev. 2015, 18, 310-328. [CrossRef]

129. Kroeger, A.; Bakhtary, H.; Haupt, F.; Streck, C. Eliminating Deforestation from the Cocoa Supply Chain; The World Bank: Washington, DC, USA, 2017.

130. Gilbert, C.L. International Commodity Agreements. In Handbook on International Trade Policy; Edward Elgar Publishing: Cheltenham, UK, 2007.

131. Van Groenendaal, W.; Vingerhoets, J. Can international commodity agreements work? J. Policy Model. 1995, 17, 257-278. [CrossRef]

132. European Commission. TARIC Consultation: Taxation and Customs Union. Available online: https://ec.europa.eu/taxation_ customs /dds2/taric/taric_consultation.jsp?callbackuri=CBU-1\&Lang=en (accessed on 22 October 2021).

133. Cadestin, C.; Gourdon, J.; Kowalski, P. Participation in Global Value Chains in Latin America. In OECD Trade Policy Papers; OECD: Paris, France, 2016. [CrossRef]

134. United Nations. Guiding Principles on Business and Human Rights; United Nations: New York, NY, USA; Geneva, Switzerland, 2011.

135. Swinnen, J. Economics and politics of food standards, trade, and development\#. Agric. Econ. 2016, 47, 7-19. [CrossRef]

136. Felbermayr, G.; Godart, O.; Langhammer, R.J.; Sandkamp, A. Chancen und Risiken eines Sorgfaltspflichtengesetzes: Kurzgutachten im Auftrag der IMPULS-Stiftung; Institut für Weltwirtschaft (ifw): Kiel, Germany, 2021.

137. Rudloff, B.; Wieck, C. Stiftung Wissenschaft und Politik. Nachhaltige Lieferketten im Agrarsektor: Wert Schöpfen Statt Zuliefern; SWP-Aktuell 2020/A 70: Berlin, Germany, 2020.

138. Kolev, G.V.; Neligan, A. Nachhaltigkeit in Lieferketten: Eine Ökonomische Bewertung von Gesetzesvorschlägen, IW-Policy Paper Nr. 5; Institut der deutschen Wirtschaft (iw): Köln, Germany, 2021; Available online: https:/ / www.iwkoeln.de/studien/galina-kolevadriana-neligan-eine-oekonomische-bewertung-von-gesetzesvorschlaegen.html (accessed on 20 November 2021).

139. Grossarth, J. Siegel, Zölle und Lieferkettengesetz: Nützen Oder Schaden sie den Kleinbauern? Available online: https: //www.weltohnehunger.org/details/siegel-z\%C3\%B6lle-und-lieferkettengesetz-n\%C3\%BCtzen-oder-schaden-sie-denkleinbauern.html (accessed on 7 October 2021). 